\title{
Relações intersetoriais e dinâmica do complexo lácteo de Minas Gerais no período 2005 a 2008
}

\author{
Eduardo Belisário Finamore ${ }^{1}$ \\ Adriano Provezano Gomes ${ }^{2}$
}

\begin{abstract}
Resumo: O artigo teve como objetivos identificar a composição e o peso setorial do complexo lácteo de Minas Gerais, bem como a dinâmica temporal da demanda agregada utilizando as matrizes de insumo-produto de 2005 e 2008. Em um primeiro momento foi avaliada as relações setoriais para o ano de 2008 por meio de indicadores de grau de autonomia e em um segundo momento analisou-se a dinâmica dos componentes da demanda agregada entre 2005 e 2008. Verificou-se que, em 2008, a produção do agrupamento formado pelos setores "Leite de vaca", "Leite resfriado" e "Produtos de laticínios” apresentou um nível de autonomia no suprimento de insumos elevado para as vendas. Entre 2005 e 2008 foi observado uma mudança estrutural importante no complexo lácteo mineiro, em que a matéria-prima "Leite de vaca" é na maior parte destinada às exportações interestaduais e não para atender a demanda intermediária do próprio estado.
\end{abstract}

Palavras-chave: Leite. Cadeia produtiva do leite. Matriz de insumo-produto. Minas Gerais.

\section{Intersectoral relations and dynamics of the milk complex of Minas Gerais}

\begin{abstract}
The article had as objective identifies the composition and sectorial weight of the dairy complex of Minas Gerais as well as the temporal dynamics of the aggregate demand using the input and output matrices of 2005 and 2008. At a first moment the sectoral relations for the year of 2008 through indicators of degree of autonomy and in a second moment the dynamics of the components of aggregate demand between 2005 and 2008 was analyzed. It was verified that, in 2008, the production of the grouping formed by the sectors "Milk of cow", "Milk cooled", and "Products of dairy" presents a high level of autonomy in the supply inputs for the sales. Between 2005 and 2008, a significant change was observed where the raw
\end{abstract}

1 Professor Titular da Faculdade de Economia da Universidade de Passo Fundo (UPF). E-mail: finamore@upf.br

2 Professor Titular da Faculdade de Economia da Universidade Federal de Viçosa (UFV). E-mail: apgomes@ufv.br. 
material "Cow's Milk" is mostly intended for interstate exports and not to meet the intermediary demand of the state itself.

Keywords: Milk. Milky's Agribusiness. Input-ouput matrix. Minas Gerais

Classificação JEL: Q13, R12

\section{Introdução}

Minas Gerais é o estado brasileiro com a maior produção de leite e o maior número de produtores do Brasil. Ao longo do tempo, o produtor de leite sempre foi desafiado a aumentar a produtividade e a qualidade da sua produção, aumentando a sua especialização produtiva e incorporando maior tecnologia no setor, representada por uma melhor genética dos animais, um manejo mais eficiente com melhoria na alimentação do rebanho e na aquisição de equipamentos de ordenha mecânica, refrigeração do leite, entre outros.

Segundo a Pesquisa Pecuária Municipal do IBGE (2016), em 2001, a produção de leite no estado aumentou de 5,981 bilhões de litros de leite em 2001 para 8,970 bilhões de litros em 2016, um aumento de produção de 49,98 \% no período. Parte desse aumento de produção ocorreu em razão do aumento do número de vacas, que passou de 4,474 milhões para 4,974 milhões de vacas em 2016, um aumento de 11,17 $\%$. No entanto, o que explica a maior parte do aumento de produção no período foi o aumento da produtividade em 34,91\%, passando de 1.337 litros por vaca em 2001 para 1.803 litros por vaca em 2016. A produtividade média da vaca de Minas Gerais é maior do que da média brasileira, que foi de 1.709 litros por vacas em 2016, mas menor do que a dos estados do sul do país. No Paraná, segundo estado de maior produção no país, a produtividade da vaca em 2016 foi de 2.916 litros por vaca e a expansão da produção no período foi de $150,32 \%$, sendo $40,96 \%$ em razão do aumento do número de vacas e $77,58 \%$ do aumento de produtividade. O terceiro estado produtor é o Rio Grande do Sul, cuja produtividade, a maior do país, foi de 3.157 litros por vaca em 2016. O aumento da produção de leite gaúcho no período foi de $107,64 \%$, sendo $21,33 \%$ explicado pelo aumento do número de vacas e $71,33 \%$ explicado pelo aumento de produtividade. Assim, a nível de produção de leite na propriedade, os anos 2000 são caracterizados por um grande aumento de produtividade, mas sabe-se que esse aumento na competitividade não é homogêneo entre todos os produtores e em todas as regiões do país, fazendo com que houvesse a expulsão do mercado de produtores de menor escala e de menor eficiência produtiva. O real impacto no número de produtores rurais só será conhecido quando houver divulgação do censo agropecuário de 2018. A Pesquisa Pecuária Municipal também revela que, em 2013, a produção de leite dos estados do Sul do país (12,547 bilhões de 
litros em 2016) ultrapassou a produção dos estados do Sudeste (11,546 bilhões de litros em 2016).

Nos anos 2000, houve também um grande aumento da capacidade de processamento da indústria láctea brasileira, que se beneficiou da expansão de crédito a taxas acessíveis de longo prazo. Isto permitiu a expansão da oferta com o aumento da durabilidade do produto. A indústria nacional promoveu um grande incentivo do aumento da qualidade do leite a nível de produtor rural, muito em função de um maior rigor na legislação, e também uma melhoria da qualidade dos derivados lácteos com o lançamento de novos produtos com novas embalagens e maior valor agregado. Do mesmo modo que o produtor, a expansão industrial não é homogênea em todo o território nacional e observa-se uma tendência à ocorrência de fusões e aquisições entre os grandes grupos internacionais e nacionais. Essa dinâmica de aquisições e fusões pode ser explicada pela volatilidade do preço e da quantidade produzida do leite, associada aos fluxos fixos de pagamentos dos empréstimos (juros e amortizações) captados pelos grandes grupos do setor, afetando os indicadores de rentabilidade e sendo um desafio para uma expansão maior do setor.

Segundo ALMEIDA et al. (2014), a produção mineira de laticínios e derivados do leite tem papel destacado na produção de alimentos do estado, não apenas pela relação com a pecuária e a bovinocultura leiteira, mas também pelo peso dentro da estrutura produtiva mineira: o setor responde aproximadamente por um terço da produção alimentícia do estado e por um quarto de toda a produção de laticínio nacional. ALMEIDA et al. (2014) observa que dentro da indústria alimentícia de Minas Gerais o maior peso é do segmento "resfriamento e preparação de leite e laticínios", enquanto na média da economia nacional tem maior importância o "abate de animais e preparação de carnes".

De uma forma geral o setor lácteo brasileiro passou por grandes transformações para aumentar a sua eficiência, tanto a nível de produtor, que viu ocorrer grandes ganhos de produtividade, quanto na atividade industrial, que diversificou a sua produção de derivados lácteos e diminuiu a perecibilidade do produto com o aumento da capacidade produtiva de leite UHT e em pó.

Nesse contexto, questiona-se: qual a dimensão econômica do complexo lácteo mineiro, qual a sua composição setorial e qual a relação entre eles? Como é a distribuição da demanda pela produção de leite natural e de derivados lácteos mineira? Em que proporção a produção do leite e seus derivados é destinada para dentro e fora do estado? Certamente responder a essas questões permitirá avaliar as políticas públicas e as estratégias empresariais para o médio e longo prazo.

Especificamente este artigo tem como objetivo verificar o grau de articulação intersetorial entre o setor de leite natural e a indústria láctea de Minas Gerais, bem como avaliar a dinâmica da demanda agregada do complexo lácteo mineiro ao longo 
do tempo. Para tanto, utiliza-se como estrutura de dados as duas últimas Matrizes de Insumo-Produto do estado de Minas Gerais, de 2005 e 2008, essa última divulgada pela Fundação João Pinheiro em 2015.

Para isto, o artigo apresenta, em sequência, o referencial teórico e metodológico utilizado. $\mathrm{Na}$ apresentação dos dados se faz uma discussão das pressuposições e do uso de Matrizes de Insumo-Produto para a "extração" de cadeias produtivas. Após, apresenta-se, com base nos resultados obtidos, uma descrição dos fluxos intersetoriais de insumos e produtos que delimitam e caracterizam o complexo lácteo mineiro e, por último, expõem-se as principais conclusões e considerações finais.

\section{Metodologia}

A dinâmica conjunta da produção da agropecuária com as agroindústrias e agrosserviços adota os termos agribusiness ou agronegócio pelos profissionais da área de economia aplicada. Um desafio é a identificação dos agrupamentos produtivos dentro dos espaços regionais, que procura aglutinar atividades altamente interrelacionadas em termos de transações intermediárias e que representa uma relativa independência com o resto das atividades de um sistema econômico.

Existem várias metodologias para esse delineamento, sendo que análises mais particularizadas podem ser implementadas usando matrizes de insumo-produto (MIP). Os agrupamentos produtivos ou clusters reúnem atividades com alto grau de integração, de modo que os intercâmbios que se dão em seu interior se tornam mais relevantes do que os que se dão com o resto do sistema. Os agrupamentos ou complexos assim definidos tendem a permanecer no tempo, marcando uma característica estrutural da economia.

Para Ramos (1998), na análise dos agrupamentos produtivos são discriminadas as compras e/ou vendas de matérias-primas diretas ou específicas - que são as que definem o caráter dos agrupamentos - e ainda as outras compras e/ou vendas de insumos ou serviços que, podendo ser importantes, apresentam vinculação relativamente uniforme com todos os setores da economia e, portanto, não se distinguem diretamente com nenhum agrupamento. Esse primeiro tipo de relação gera os encadeamentos para trás e para frente, que integram as atividades dos agrupamentos produtivos; o segundo tipo dá lugar a encadeamentos para "os lados", isto é, para atividades que não se integram verticalmente ao agrupamento produtivo. Segundo o autor, dentro do esquema de um agrupamento produtivo típico, baseado, por exemplo, no processamento de recursos naturais, encontram-se encadeamentos para trás por meio de compras de insumos químicos, maquinário específico, serviços especializados e outros. Já encadeamentos para frente são encontrados pelas vendas para outros setores produtivos que serão maiores quanto mais difundido for o 
produto utilizado como insumo das demais indústrias. Os encadeamentos para os lados são energia, comércio e serviços financeiros.

Para identificar esse conjunto de encadeamentos de um agrupamento, a metodologia empregada usa as informações estatísticas das relações intersetoriais contidas nas Matrizes de Insumo-Produto.

O Quadro 1 mostra o esquema de apresentação dos dados, conhecido como Matriz de Transações. Nas linhas, localizam-se as vendas dos setores, e nas colunas, as compras dos setores.

Quadro 1 - Matriz de transações de um modelo de insumo-produto.

\begin{tabular}{|c|c|c|c|c|c|c|c|c|c|}
\hline & \multicolumn{4}{|c|}{ FLUXO INTERMEDIÁRIO } & \multicolumn{4}{|c|}{ DEMANDA FINAL } & \\
\hline \multirow{7}{*}{ 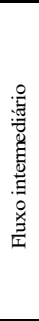 } & Setores & 1 & 2 & $\begin{array}{c}\text { Vendas } \\
\text { Intermediárias }\end{array}$ & Consumo Famílias & Governo & Investimento & Exportações & Demanda Total \\
\hline & 1 & $x_{11}$ & $x_{12}$ & $X_{I T}$ & $F_{l}$ & $G_{I}$ & $I_{1}$ & $E_{1}$ & $X_{1}$ \\
\hline & 2 & $x_{21}$ & $x_{22}$ & $X_{2 T}$ & $F_{2}$ & $G_{2}$ & $I_{2}$ & $E_{2}$ & $X_{2}$ \\
\hline & Compras Intermediárias & $X_{T I}$ & $X_{T 2}$ & & & & & & $V B P$ \\
\hline & Importações - M & $m_{1}$ & $m_{2}$ & $M I_{T T}$ & & & & & \\
\hline & Impostos indiretos líquidos & $t_{l}$ & $t_{2}$ & $T I_{T T}$ & & & & & \\
\hline & Subtotal & $C I_{I}$ & $\mathrm{CI}_{2}$ & $C I_{T T}$ & & & & & \\
\hline \multirow{4}{*}{ 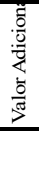 } & Salários & $s_{1}$ & $s_{2}$ & $S_{T T}$ & & & & & \\
\hline & Impostos e Subsídios & $t^{\prime}{ }_{l}$ & $t^{\prime}{ }_{2}$ & $T^{\prime} T T$ & & & & & \\
\hline & Excedente Operacional Bruto & $l_{1}$ & $l_{2}$ & $L_{T T}$ & & & & & \\
\hline & Produção Total & $X_{1}$ & $X_{2}$ & $V B P$ & & & & & \\
\hline
\end{tabular}

Fonte: elaboração própria

Observam-se três tipos de relações. A primeira ocorre entre as empresas cujo fluxo de transações intermediárias pode ser representado por uma matriz X, em que cada elemento - Xij - representa o valor da produção do setor i consumido no setor $\mathrm{j}$. Dentro das transações intermediárias, existe uma matriz $M$ de importações (interestaduais e internacionais) e uma matriz TI de impostos indiretos, menos os subsídios. Uma segunda relação ocorre entre as empresas e as famílias, cuja produção destinada para a demanda final é dividida em quatro categorias: consumo das famílias, consumo do governo, investimentos líquidos e exportações. A terceira relação, também entre as empresas e as famílias, mostra como o valor adicionado pelos setores remuneram os fatores de produção utilizados nos processos produtivos. Parte do valor adicionado a preços básicos é destinada à remuneração dos trabalhadores na forma de salários e contribuições previdenciárias; parte é destinada ao governo, na forma de impostos que incidem sobre a renda e a propriedade. Por fim, parte do valor 
adicionado dos setores é destinada à remuneração do capital investido nas atividades produtivas na forma de excedente operacional bruto, uma proxy do lucro bruto.

Para a correta identificação dos agrupamentos produtivos, é necessário que os setores sejam agrupados com certo grau de homogeneidade nos produtos que os compõem, sendo sugerido trabalhar com matrizes de alto grau de desagregação. $\mathrm{O}$ critério para verificar o grau de inter-relação existente dentro de um agrupamento produtivo foi o coeficiente estatístico denominado "grau de autonomia" de cada agrupamento. Tal procedimento metodológico foi utilizado por Vaillant (1999) para delimitar o complexo produtivo lácteo do Uruguai.

Esse coeficiente mede a relação das compras intermediárias (vendas intermediárias), que se realizam dentre o agrupamento produtivo como proporção das compras intermediárias totais (vendas intermediárias totais) do agrupamento produtivo.

Autonomia de vendas do setor $i=\sum_{j=1}^{k} x_{i j} / \sum_{j=1}^{n} x_{i j}$

Autonomia de compras do setor $j=\sum_{i=1}^{k} x_{i j} / \sum_{i=1}^{n} x_{i j}$ Autonomia global $=\sum_{i=1}^{k} \sum_{j=1}^{k} x_{i j} / \sum_{i=1}^{n} \sum_{j=1}^{n} x_{i j}$

em que: $\quad k=$ setores que pertencem ao agrupamento

$\mathrm{n}=$ todos os setores

Quando se identificam agrupamentos produtivos com alto grau de autonomia em vendas, trata-se de um agrupamento organizado em torno das atividades vendedoras de insumos ou matérias-primas. Já quando a autonomia em compras é alta, o agrupamento produtivo está organizado em torno de uma atividade basicamente final.

O método empregado para escolher um agrupamento produtivo foi selecionar os conjuntos de setores de forma que os perfis linha (estrutura das vendas intermediárias por setor) e os perfis coluna (estrutura de compras intermediárias por setor) tenham um valor do parâmetro de autonomia do setor analisado (em vendas ou em compras) de $100 \%$.

\subsection{Fonte de dados}

Os dados utilizados foram extraídos das matrizes de insumo-produto e das contas econômicas integradas de Minas Gerais do ano de 2005 e 2008, fornecidas pela Fundação João Pinheiro (FJP), sendo as mais atualizadas quando houve a elaboração deste artigo. Os valores monetários são a preços básicos e encontram-se em milhões 
de reais. A Tabela de Recursos e Usos apresenta os fluxos de oferta e demanda dos bens e serviços para 40 setores de atividades e 85 produtos.

Para a compilação das matrizes, adotou-se o modelo produto x produto (matriz de dimensão 85 x 85). O Anexo 2 apresenta uma tabela de correspondência entre setores e produtos para a Matriz de insumo-produto de 2008 de Minas Gerais. Nesse caso, considera-se que a tecnologia é determinada pelo produto, sendo a tecnologia das atividades uma combinação da tecnologia dos produtos que produz. Os procedimentos para a compilação das matrizes são detalhados por Ramos (1996).

A autonomia de vendas e a autonomia de compras descrita na metodologia referem-se a três setores centrais do complexo lácteo identificados junto aos 85 produtos da matriz de insumo-produto de Minas Gerais: "Leite de vaca e de outros animais - Setor 9"; "Leite resfriado, esterilizado e pasteurizado - Setor 23"; e "Produtos de laticínios e sorvetes - Setor 24". Esses três setores centrais dão origem a seis agrupamentos setoriais, e para cada setor, se analisa o perfil linha (vendas) e o perfil coluna (compras), conforme apresentado nos resultados deste artigo.

Cabe dizer que, considerando as propriedades implícitas na formulação do sistema de Leontief associadas às matrizes de insumo-produto, a análise do perfil linha é mais confiável do que os resultados obtidos na análise do perfil coluna, pois os dados da matriz de consumo intermediário e da matriz de demanda final utilizados para gerar a matriz de insumo-produto final fornecem o destino da produção por "produto", absorvida por setores e por componente de demanda final.

Assim, a nível agregado, sabe-se exatamente quanto da produção de cada "produto" foi para o consumo intermediário e quanto da produção de cada "produto" foi para o consumo final em cada um dos seus componentes.

No entanto, para se obter os valores dos insumos comprados de forma desagregada por produto, a metodologia de insumo-produto faz uma expansão e os produtos irão refletir a tecnologia dos "setores" que foram obtidos pela agregação dos dados dos produtos que o compõem. Isto ocorre em razão do sistema estatístico das contas nacionais e regionais estabelecer duas referências: atividades e produtos. Com isso, os resultados de compras intermediárias de cada "produto" e de outros gastos, como importação e com a remuneração dos fatores de produção (valor adicionado) a nível mais desagregado, ficam comprometidos, refletindo uma média "setorial" e não valores de cada agrupamento de produtos isoladamente.

Por exemplo, a indústria de "Alimentos e bebidas" do estado de Minas Gerais da matriz de insumo-produto de 2008, conforme divulgado pela Fundação João Pinheiro, é composta por 14 agrupamentos de produtos: Abate e preparação de produtos de carne; Carne de aves fresca, refrigerada ou congelada; Conservas de frutas, legumes e outros vegetais; Óleo de soja em bruto e tortas, bagaços e farelo de soja; Óleo de soja refinado, outros óleos vegetais exceto milho e óleos de origem animal não comestíveis; Leite 
resfriado, esterilizado e pasteurizado; Produtos do laticínio e sorvetes; Arroz beneficiado e produtos derivados; Farinha de trigo e derivados; Óleos de milho, amidos e féculas vegetais e rações; Produtos das usinas e do refino de açúcar; Café torrado, moído e solúvel; Outros produtos alimentares; e Bebidas.

A atividade "Pecuária e pesca" é composta por cinco agrupamentos de produtos: Bovinos e outros animais vivos; Leite de vaca e de outros animais; Suínos vivos; Aves vivas; e Ovos de galinha e de outras aves.

Assim, ao se relacionar a atividade "Pecuária e pesca" com a atividade "Alimentos e bebidas", conhece-se os valores de cada produto da pecuária que foram para a indústria de alimentos (matriz $5 \times 1$ ). Mas quando se quer relacionar os cinco produtos da atividade "Pecuária" com os 14 produtos da atividade "Alimentos e bebidas" (matriz $5 \times 14$ ), esses valores são distribuídos entre as diferentes "caselas", conforme o faturamento de cada agrupamento de produto. Porém, claramente alguns valores são falsos, devendo ser modificados pelo analista. Claramente, o "Leite de vaca e de outros animais" trata-se de insumos do agrupamento "Leite resfriado, esterilizado e pasteurizado" e de "Produtos de laticínios e sorvetes", e não de insumos dos subsetores "Óleo de soja" ou "Óleo de milho" ou "Refino de açúcar". Em outras palavras, claramente o leite foi comprado pela indústria de alimentos, mas não por todos os subsetores que o compõem.

Em resumo, os dados, a nível mais desagregado, matriz tecnologia produtoproduto, por sofrer uma transformação estatística deve ser modificado pelo analista, mas dada a deficiência de informações, não resulta em valores exatos e sim em aproximações que devem ser alvo de estudos adicionais. Esses esclarecimentos se tornam necessários para dizer que é preciso avançar no desenvolvimento do sistema estatístico brasileiro e ainda no seu uso para delineamento de cadeias produtivas individuais.

\section{Resultados e discussão}

Para verificar o grau de articulação entre o setor de leite natural e a indústria láctea em Minas Gerais para o ano de 2008, e desses setores com outros setores da economia, foram selecionados seis agrupamentos de setores. Dois agrupamentos para o setor de "Leite de vaca e de outros animais"; dois agrupamentos para o setor "Leite resfriado, esterilizado e pasteurizado"; e dois agrupamentos para o setor da indústria de lácteos "Produtos de laticínios e sorvetes", de acordo com os perfis linha (estrutura das vendas intermediárias por setor) e de acordo com os perfis coluna (estrutura de compras intermediárias por setor). A seleção dos setores de cada agrupamento tem o objetivo de que o valor do parâmetro de autonomia do setor analisado (em vendas ou em compras) seja de $100 \%$. 
A seguir, são apresentados os seis agrupamentos com suas principais relações, com o objetivo de apresentar esquematicamente a visão sistêmica do complexo lácteo mineiro.

Primeiro agrupamento: $\mathrm{O}$ primeiro agrupamento, apresentado na Tabela $1 \mathrm{e}$ na Figura 1, mostra as informações do perfil linha do setor de "Leite de vaca e de outros animais". Esse agrupamento é formado pelos setores "Leite de vaca e de outros animais" (9), "Leite resfriado, esterilizado e pasteurizado" (23), e "Leite, produtos de laticínios e sorvetes" (24), classificados como setores centrais.

Tabela 1 - Análise do perfil linha do setor "Leite de vaca e de outros animais"

\begin{tabular}{|c|c|c|c|c|c|c|}
\hline $\begin{array}{c}\mathbf{N} \\
\mathbf{0}\end{array}$ & SETORES & $\begin{array}{c}\text { Leite de } \\
\text { vaca e de } \\
\text { outros } \\
\text { animais }\end{array}$ & $\begin{array}{c}\text { Leite } \\
\text { resfriado, } \\
\text { esterilizado e } \\
\text { pasteurizado }\end{array}$ & $\begin{array}{c}\text { Produtos } \\
\text { do laticínio } \\
\text { e sorvetes }\end{array}$ & $\begin{array}{c}\text { AUTONOMI } \\
\text { A DE } \\
\text { VENDAS }\end{array}$ & VI/VBP \\
\hline $\mathbf{9}$ & $\begin{array}{c}\text { Leite de vaca e de } \\
\text { outros animais }\end{array}$ & $3,6 \%$ & $44,6 \%$ & $51,7 \%$ & $100,0 \%$ & $25,2 \%$ \\
\hline $\mathbf{2 3}$ & $\begin{array}{c}\text { Leite resfriado, } \\
\text { esterilizado e } \\
\text { pasteurizado }\end{array}$ & $0,0 \%$ & $29,9 \%$ & $34,7 \%$ & $64,6 \%$ & $40,1 \%$ \\
\hline 24 & $\begin{array}{c}\text { Produtos do laticínio e } \\
\text { sorvetes }\end{array}$ & $0,0 \%$ & $0,0 \%$ & $49,5 \%$ & $49,5 \%$ & $17,0 \%$ \\
\hline
\end{tabular}

Fonte: Elaborado com base no Anexo 1.

Figura 1 - Decomposição das vendas intermediárias do complexo lácteo mineiro - 2008

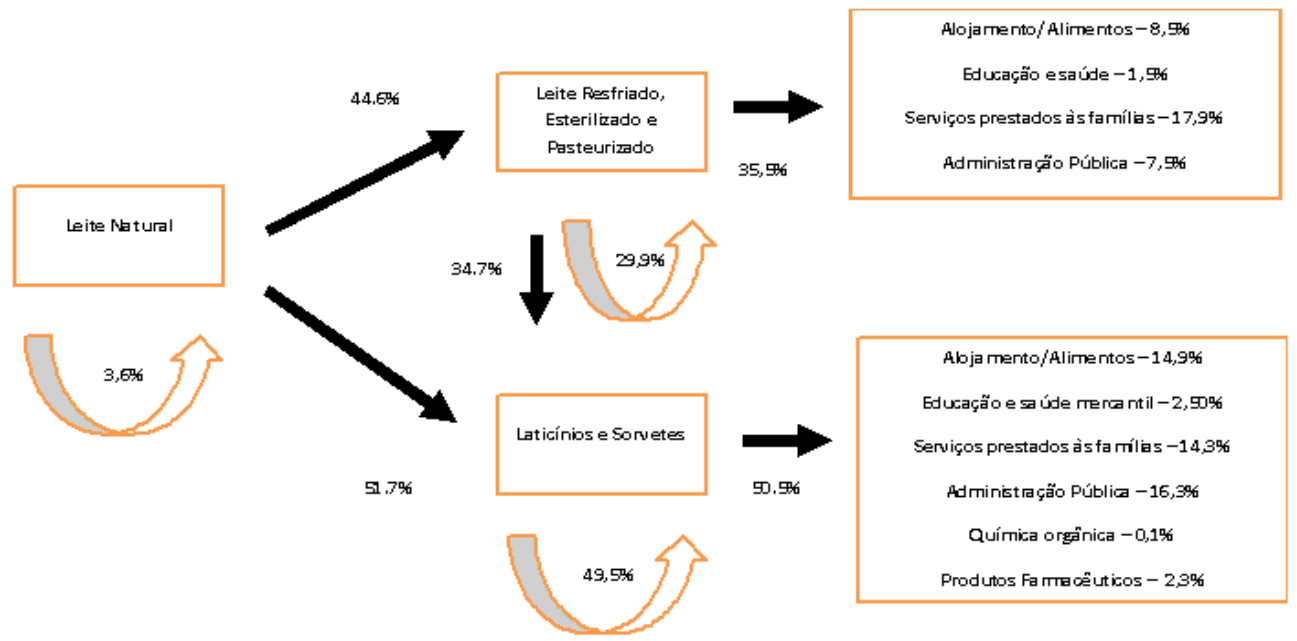

Fonte: Elaborado com base na Tabela 1 e na MIP 2008. 
Observa-se na Tabela 1 que a autonomia das vendas intermediárias do setor 9, “Leite de vacas e de outros animais", é de $100 \%$, sendo 3,6\% das vendas intermediárias destinadas ao próprio setor, 44,6\% destinadas ao setor de "Leite resfriado, esterilizado e pasteurizado" (setor 23) e 51,7 \% ao setor de "Produtos do laticínio e de sorvetes" (setor 24).

Nesse primeiro agrupamento, o setor de "Leite resfriado, esterilizado e pasteurizado" apresenta um grau de autonomia de vendas intermediárias de 64,6\%, dos quais 29,9 \% são comercializados no próprio setor e 34,7 \% são vendidos ao setor de "Produtos de laticínios e sorvetes". Portanto, 35,4 \% de suas vendas intermediárias são destinados a outros setores, que farão parte do segundo agrupamento produtivo, detalhados na Figura 1 e na Tabela 3.

O setor de "Produtos de laticínios e sorvetes" apresenta um grau de autonomia de vendas intermediárias de $49,5 \%$, as quais são comercializadas no próprio setor, tendo portanto, $50,5 \%$ de suas vendas intermediárias destinadas a outros setores, que farão parte do terceiro agrupamento produtivo, detalhados na Figura 1 e na Tabela 4.

A última linha da Tabela 1 mostra que $72,4 \%$ das vendas intermediárias são negociadas com esses três setores centrais da cadeia láctea mineira (grau de autonomia de vendas agregado).

Observa-se também, pela relação entre vendas intermediárias e pelo valor bruto da produção (VI/VBP), que em 2008, apenas 25,2 \% do leite de vaca e de outros animais foram destinados à demanda intermediária mineira, e portanto, o restante, 74,8 $\%$, foi para a demanda final, em sua maior parte para a exportação para outros estados brasileiros. Ou seja, o beneficiamento do leite produzido em Minas Gerais está sendo feito pelas indústrias de outros estados. Esses resultados diferem dos encontrados por Finamore \& Gomes (2016) na análise da cadeia láctea mineira para o ano de 2005, sob a mesma metodologia, em que $94,4 \%$ do leite mineiro era industrializado dentro do próprio estado, sendo o restante comprado pelas famílias. Essa mudança estrutural brusca pode estar ligada a algum aspecto fiscal entre os estados, provocando uma mudança na dinâmica da industrialização dos derivados lácteos do Brasil. A mudança estrutural da demanda intermediária e final dos setores do complexo lácteo de Minas Gerais entre 2005 e 2008 é analisada na parte final deste artigo. 
Figura 2 - Distribuição das vendas intermediárias e finais do complexo lácteo mineiro $-2008$

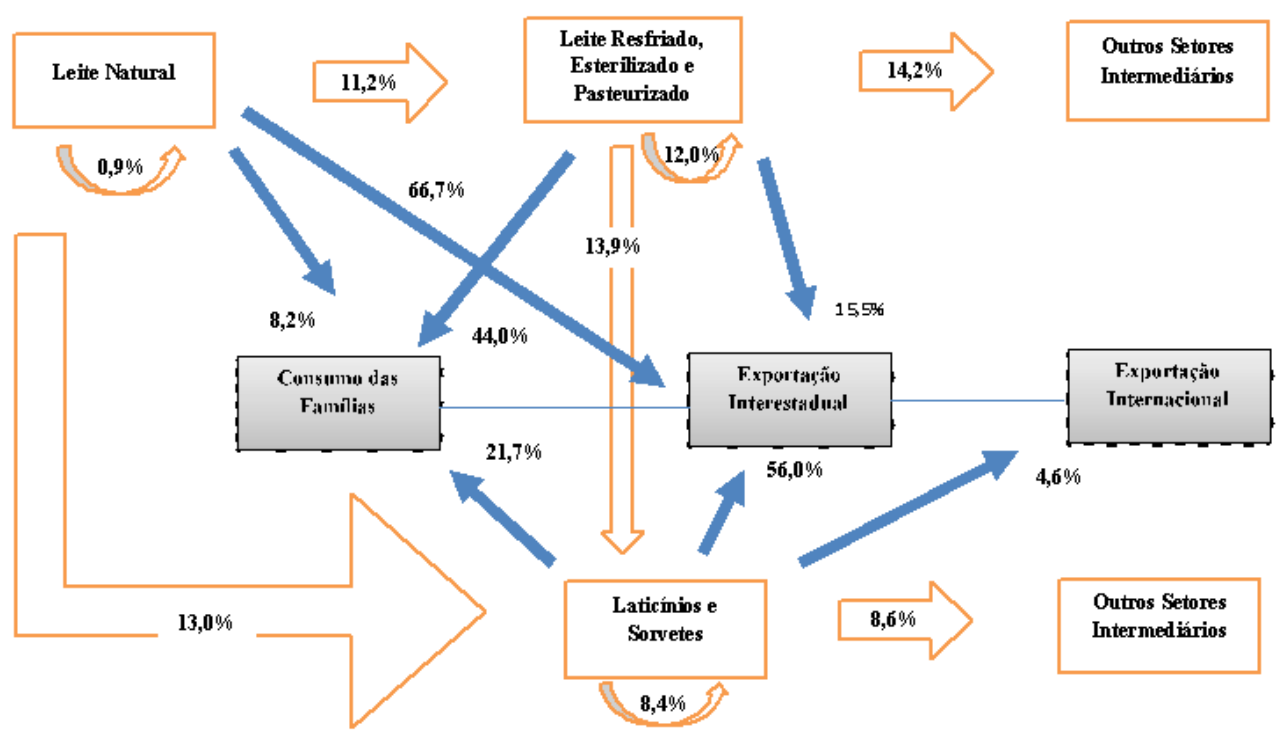

Fonte: Elaborado com base no Anexo 1 e na MIP 2008.

A Figura 2 mostra, de forma integrada, a distribuição das vendas dos três setores centrais da cadeia láctea mineira entre vendas intermediárias e finais. A demanda final do complexo lácteo é distribuída entre o consumo das famílias e as exportações interestaduais e internacionais. Verifica-se, assim, que o setor de leite natural destinou $11,2 \%$ da sua produção para o setor de leite resfriado e 13,0 \% para o setor de laticínios e sorvetes e, como destino final, 66,7 \% das vendas para a exportação a outros estados da federação e $8,2 \%$ para o consumo das famílias. $O$ setor de laticínios destinou $8,4 \%$ da sua produção para o próprio setor e $8,6 \%$ para outros setores intermediários, e, como destino final, $56,0 \%$ das vendas para a exportação a outros estados da federação, 4,6 \% para vendas internacionais e 21,7 \% para o consumo das famílias. O setor de leite resfriado, esterilizado e pasteurizado destinou $12,0 \%$ de sua produção para o próprio setor, $13,9 \%$ para o setor de laticínios e sorvetes e 14,2 \% para outros setores intermediários, sendo que $44,0 \%$ das vendas foram para o consumo das famílias e $15,5 \%$ para a exportação interestadual.

A Tabela 2 mostra a análise das compras de insumos intermediários dos três setores desse agrupamento (perfil coluna). Verifica-se pela autonomia de compras total que esses três setores fornecem $43,8 \%$ de todos os insumos intermediários 
produzidos dentro do estado e utilizados por eles mesmos, sendo o restante $(56,2$ $\%$ ) fornecido por outros setores da economia mineira, a ser observado nos demais agrupamentos mais adiante. Verifica-se que, individualmente, o setor de leite de vaca possui uma autonomia de compras de somente $3,5 \%$ dentro desse agrupamento, seguido pelo setor de laticínios e sorvetes, com autonomia de compras de $52,5 \%$ e pelo setor de resfriamento e pasteurização do leite com uma autonomia de compras de $67,4 \%$.

Cabe dizer que, além de insumos intermediários produzidos em Minas Gerais, os setores produtivos adquirem ainda mercadorias importadas de outros estados e países e ainda pagam tributos que incidem sobre esses insumos. A relação CI/VBP mostra a proporção total de insumos intermediários utilizados por esses três setores e fornecidos por eles mesmos, seja produzido em Minas Gerais ou em outros estados e países. De forma agregada, o fornecimento desses três setores foi de 54,6 \%, sendo, portanto, o restante $(45,4 \%)$ adquirido de outros setores da economia.

Por fim, o valor adicionado pode ser obtido subtraindo o consumo intermediário pelo valor bruto da produção. Observa-se, na última linha da Tabela 2, que o setor de leite de vaca e de outros animais possui um coeficiente de valor adicionado de $60,0 \%$, sendo que o valor adicionado do setor de leite resfriado e pasteurizado é de apenas $23,0 \%$ e o do setor de laticínios e sorvetes é de $41,6 \%$. Percebe-se que se a produção de leite de vaca fosse industrializada dentro do próprio estado haveria um incremento no valor adicionado estadual nas proporções de transformação inerentes a esses setores produtivos.

Tabela 2 - Análise do perfil coluna do setor "Leite de vaca e de outros animais"

\begin{tabular}{|c|c|c|c|c|c|}
\hline № & SETORES & $\begin{array}{l}\text { Leite de } \\
\text { vaca e de } \\
\text { outros } \\
\text { animais }\end{array}$ & $\begin{array}{c}\text { Leite resfriado, } \\
\text { esterilizado e } \\
\text { pasteurizado }\end{array}$ & $\begin{array}{l}\text { Produtos do } \\
\text { laticínio e } \\
\text { sorvetes }\end{array}$ & TOTAL \\
\hline 9 & Leite de vaca e de outros animais & $3,5 \%$ & $47,0 \%$ & $22,1 \%$ & \\
\hline 23 & $\begin{array}{l}\text { Leite resfriado, esterilizado e } \\
\text { pasteurizado }\end{array}$ & $0,0 \%$ & $20,4 \%$ & $9,6 \%$ & \\
\hline \multirow[t]{4}{*}{24} & Produtos do laticínio e sorvetes & $0,0 \%$ & $0,0 \%$ & $20,8 \%$ & \\
\hline & AUTONOMIA DE COMPRAS & $3,5 \%$ & $67,4 \%$ & $52,5 \%$ & $43,8 \%$ \\
\hline & CI/VBP & $40,0 \%$ & $77,0 \%$ & $58,4 \%$ & $54,6 \%$ \\
\hline & VA/VBP & $60,0 \%$ & $23,0 \%$ & $41,6 \%$ & $45,4 \%$ \\
\hline
\end{tabular}

Fonte: Elaborado com base no Anexo 1 e na MIP 2008.

Como dito na descrição dos dados, a análise do perfil linha (Tabela 1) é mais confiável do que a análise do perfil coluna. Esses dados, a nível mais desagregado, matriz tecnologia produto-produto, por sofrerem uma transformação estatística e 
serem alterados parcialmente pelos analistas, devem ser vistos como valores aproximados e não como valores exatos, e devem ser alvo de estudos adicionais.

Nesse contexto, o valor adicionado do subsetor de "Leite resfriado" de 23,0 \% e o valor adicionado do subsetor de "Produtos de laticínios" de 41,6 \% revela-se maior do que a média de 17,4\% observada para a indústria de "Alimentos e bebidas" do estado de Minas Gerais em 2008, conforme divulgado pela Fundação João Pinheiro, composto por 14 subsetores. Observa-se também que para o subsetor "Leite de vaca e de outros animais" a proporção do Valor adicionado sobre o Valor bruto da produção de $60,0 \%$ também foi maior do que a média de 57,7 \% observada na pecuária mineira composta por cinco subsetores.

Segundo agrupamento: A Tabela 3 mostra um segundo agrupamento, com base no perfil linha do setor de "Leite resfriado, esterilizado e pasteurizado", em que a autonomia das vendas intermediárias seja $100 \%$. A segunda coluna mostra que $29,9 \%$ das vendas intermediárias de leite resfriado ocorrem dentro do próprio setor observando que esse setor capta parte do leite natural produzido no estado e contém empresas responsáveis pelo resfriamento (postos de resfriamento) e por empresas que comercializam o leite pasteurizado - e para indústrias de laticínios. Além disso, 34,7 $\%$ do leite resfriado é vendido para as indústrias de laticínios e sorvetes, 17,9\% para empresas de serviços prestados às famílias. Em menor parcela, o leite resfriado é destinado também aos setores de serviços de alojamento e alimentação $(8,5 \%)$ e à administração pública $(7,5 \%)$. Esses percentuais de vendas intermediárias também podem ser observados na Figura 1.

Esse conjunto de seis setores que adquirem o leite resfriado é destino também de $97,7 \%$ das vendas intermediárias do setor de laticínios e sorvetes. Nota-se, ainda, que as compras governamentais de produtos lácteos são classificadas como vendas intermediárias e não como vendas para a demanda final.

Tabela 3 - Análise do perfil linha do setor "Leite resfriado, esterilizado e pasteurizado" - grau de autonomia de vendas e compras

\begin{tabular}{ccccc}
\hline \multirow{2}{*}{ № } & SETORES & $\begin{array}{c}\text { VENDAS } \\
(\%)\end{array}$ & $\begin{array}{c}\text { AUTONOMIA } \\
\text { DE VENDAS }\end{array}$ & $\begin{array}{c}\text { AUTONOMIA } \\
\text { DE COMPRAS }\end{array}$ \\
\hline 23 & Leite resfriado, esterilizado e pasteurizado & $29,9 \%$ & $100,0 \%$ & $20,6 \%$ \\
24 & Produtos do laticínio e sorvetes & $34,7 \%$ & $97,7 \%$ & $30,6 \%$ \\
80 & Serviços de alojamento e alimentação & $8,5 \%$ & $43,6 \%$ & $10,5 \%$ \\
82 & Educação mercantil e saúde mercantil & $1,5 \%$ & $67,0 \%$ & $7,9 \%$ \\
83 & Serviços prestados às famílias e associativos & $17,9 \%$ & $17,8 \%$ & $16,4 \%$ \\
85 & Administração pública & $7,5 \%$ & $0,0 \%$ & $7,1 \%$ \\
\hline & TOTAL & $100,0 \%$ & $69,6 \%$ & $18,3 \%$ \\
\hline
\end{tabular}

Fonte: Dados da pesquisa. 
Do mesmo modo, deve ser observado que o setor de leite natural não faz parte desse agrupamento, pois, embora ele seja fornecedor para o setor de leite resfriado, o objetivo desse agrupamento é analisar os clientes do setor, ou seja, o destino das vendas intermediárias. Assim, a autonomia de compras do setor de leite resfriado e do setor de produtos de laticínio é muito baixa, de 20,6\% e 30,6\%. Ou seja, esses percentuais correspondem à parcela das compras desses setores de insumos estaduais fornecidos por esses seis setores e não contempla o seu principal fornecedor, que é o de leite natural.

Terceiro agrupamento: A Tabela 4 mostra um terceiro agrupamento, com base no perfil linha do setor "Produtos do laticínio e sorvetes", de modo que a autonomia das vendas intermediárias seja de $100 \%$. A segunda coluna mostra que $49,5 \%$ das vendas intermediárias de produtos do laticínio e sorvetes ocorrem dentro do próprio setor, revelando uma alta interação entre os laticínios de Minas Gerais. Além disso, 16,3 $\%$ dos derivados lácteos são vendidos para a administração pública, 14,9\% para os setores de serviços de alojamento e alimentação, e 14,3\% para as empresas de serviços prestados às famílias e aos associativos. Em menor parcela, os produtos do laticínio e sorvetes são destinados também ao setor de "Educação mercantil e saúde mercantil" $(2,5 \%)$, ao setor de "Produtos farmacêuticos" $(2,3 \%)$, e ao setor de "Produtos químicos orgânicos” $(0,1 \%)$. Esses percentuais de vendas intermediárias do setor "Produtos do laticínio e sorvetes" também podem ser observados na Figura 1.

Tabela 4 - Análise do perfil linha do setor "Produtos do laticínio e sorvetes" - grau de autonomia de vendas e compras

\begin{tabular}{|c|c|c|c|c|}
\hline № & SETORES & VENDAS & $\begin{array}{c}\text { AUTONOMI } \\
\text { A DE } \\
\text { VENDAS } \\
\end{array}$ & $\begin{array}{l}\text { AUTONOMIA } \\
\text { DE COMPRAS }\end{array}$ \\
\hline 24 & Produtos do laticínio e sorvetes & $49,5 \%$ & $100,0 \%$ & $21,1 \%$ \\
\hline 44 & Produtos químicos orgânicos & $0,1 \%$ & $3,3 \%$ & $1,9 \%$ \\
\hline 46 & Produtos farmacêuticos & $2,3 \%$ & $68,2 \%$ & $11,7 \%$ \\
\hline 80 & Serviços de alojamento e alimentação & $14,9 \%$ & $35,2 \%$ & $8,0 \%$ \\
\hline 82 & Educação mercantil e saúde mercantil & $2,5 \%$ & $66,3 \%$ & $7,9 \%$ \\
\hline 83 & Serviços prestados às famílias e associativos & $14,3 \%$ & $16,7 \%$ & $10,2 \%$ \\
\hline \multirow[t]{2}{*}{85} & Administração pública & $16,3 \%$ & $0,0 \%$ & $6,7 \%$ \\
\hline & Total & $100,0 \%$ & $45,3 \%$ & $3,1 \%$ \\
\hline
\end{tabular}

Fonte: dados da pesquisa.

A autonomia de compras do setor de produtos de laticínio nesse agrupamento de sete setores é de apenas $21,1 \%$, pois este não contempla os seus principais fornecedores, que é o de leite natural e o de leite resfriado. 
Quarto agrupamento: $\mathrm{Na}$ Tabela 5, apresenta-se a composição setorial das compras intermediárias de insumos estaduais realizadas pelo setor de Leite de vaca e de outros animais, de modo que o grau de autonomia seja de $100 \%$.

Com isso, percebe-se que, como observado no primeiro agrupamento, além dos $3,5 \%$ das compras intermediárias fornecidas pelo próprio setor, existem ainda $96,5 \%$ das compras de insumos diretos que são fornecidos por outros 28 setores da economia mineira.

Observa-se que, dentre os mais importantes, destaca-se "Óleos de milho, amidos e féculas vegetais e rações" (25,5 \%), "Produtos químicos inorgânicos" (14,0 \%) e "Milho em grão" (10,23\%), claramente setores ligados ao fornecimento e a produção da alimentação das vacas e outros animais. O setor de comércio participa com 10,42\% das compras intermediárias do setor de leite natural. Nota-se que os setores de leite beneficiado e de produtos de laticínios não fazem parte desse agrupamento, pois eles não são fornecedores de insumos do setor de "Leite de vaca e de outros animais". A classificação dos insumos diretos a esse nível de análise deve ser interpretada em termos qualitativos, dado que o nível de informações disponível impede de serem mais precisos.

A Tabela 5 também informa, para cada um dos setores, o grau de autonomia de compras. Observa-se que existem vários setores nesse agrupamento que também possuem alto grau de autonomia de compras, acima de $97,00 \%$ como milho em grão, soja em grão, produtos da exploração florestal e da silvicultura, cana-de-açúcar e café em grão.

Tabela 5 - Análise do perfil Coluna do setor "Leite de vaca e de outros animais"

\begin{tabular}{cccc}
\hline No & SETORES & Compras (\%) & $\begin{array}{c}\text { Autonomia de } \\
\text { compras }\end{array}$ \\
\hline 27 & Óleos de milho, amidos e féculas vegetais e rações & $25,5 \%$ & $69,1 \%$ \\
43 & Produtos químicos inorgânicos & $14,0 \%$ & $83,4 \%$ \\
74 & Comércio & $10,4 \%$ & $72,7 \%$ \\
1 & Milho em grão & $10,2 \%$ & $97,1 \%$ \\
41 & Outros produtos do refino de petróleo e coque & $6,9 \%$ & $72,9 \%$ \\
72 & Produção e distribuição de eletricidade, gás, água, esgoto e limpeza & & \\
76 & urbana & $5,5 \%$ & $82,9 \%$ \\
8 & Serviços de informação & $4,3 \%$ & $73,5 \%$ \\
9 & Bovinos e outros animais vivos & $3,7 \%$ & $93,6 \%$ \\
78 & Leite de vaca e de outros animais & $3,5 \%$ & $100,0 \%$ \\
75 & Atividades imobiliárias e aluguéis & $2,8 \%$ & $42,7 \%$ \\
17 & Transporte, armazenagem e correios & $2,4 \%$ & $87,7 \%$ \\
47 & Minerais não metálicos & $2,2 \%$ & $69,8 \%$ \\
& Outros produtos e serviços da lavoura & $1,8 \%$ & $98,5 \%$ \\
& Defensivos agrícolas & $1,4 \%$ & $75,9 \%$ \\
& & & Continua
\end{tabular}




\begin{tabular}{|c|c|c|c|}
\hline \multicolumn{4}{|c|}{ Continuação } \\
\hline 77 & Intermediação financeira, seguros e previdência complementar & $1,1 \%$ & $70,7 \%$ \\
\hline 3 & Soja em grão & $1,1 \%$ & $98,6 \%$ \\
\hline 30 & Outros produtos alimentares & $1,0 \%$ & $69,0 \%$ \\
\hline 7 & Produtos da exploração florestal e da silvicultura & $0,5 \%$ & $98,4 \%$ \\
\hline 46 & Produtos farmacêuticos & $0,4 \%$ & $64,3 \%$ \\
\hline 59 & Produtos de metal - exclusive máquinas e equipamento & $0,3 \%$ & $41,0 \%$ \\
\hline 2 & Cana-de-açúcar & $0,1 \%$ & $99,0 \%$ \\
\hline 79 & Serviços de manutenção e reparação & $0,1 \%$ & $85,0 \%$ \\
\hline 83 & Serviços prestados às famílias e associativos & $0,1 \%$ & $53,1 \%$ \\
\hline 42 & Álcool & $0,1 \%$ & $83,7 \%$ \\
\hline 52 & Artigos de plástico & $0,1 \%$ & $55,0 \%$ \\
\hline 6 & Café em grão & $0,1 \%$ & $99,2 \%$ \\
\hline 70 & Produtos de madeira e das indústrias diversas & $0,1 \%$ & $69,9 \%$ \\
\hline \multirow[t]{2}{*}{68} & Peças e acessórios para veículos automotores & $0,1 \%$ & $59,9 \%$ \\
\hline & $\begin{array}{c}\text { SUBTOTAL } \\
\end{array}$ & $100,0 \%$ & $74,6 \%$ \\
\hline
\end{tabular}

Fonte: Dados da pesquisa.

Quinto agrupamento: $\mathrm{Na}$ Tabela 6, apresenta-se a composição setorial das compras intermediárias de insumos estaduais realizadas pelo setor de leite resfriado, esterilizado e pasteurizado de modo que o grau de autonomia seja de $100 \%$.

Com isso, percebe-se que, como observado no primeiro agrupamento (Tabela 2), além dos $20,4 \%$ das compras intermediárias fornecidas pelo próprio setor, e dos $47,0 \%$ das compras intermediárias advindas do setor de "Leite de vaca e de outros animais", existem ainda $32,6 \%$ de insumos diretos que são fornecidos por outros 29 setores da economia mineira. Observa-se que, dentre os mais importantes, destaca-se "Comércio" (12,2\%), "Transporte, armazenagem e correios" (4,1\%), e "Serviços prestados às empresas” (3,1 \%), setores ligados à distribuição da produção.

A Tabela 6 também informa para cada um dos setores o grau de autonomia de compras. Observa-se que existem vários setores nesse agrupamento que também possuem alto grau de autonomia de compras, o que pode ser explicado pelo grande número de setores envolvidos. 
Tabela 6 - Análise do perfil coluna do setor "Leite resfriado, esterilizado e pasteurizado"

\begin{tabular}{|c|c|c|c|}
\hline № & SETORES & $\begin{array}{c}\text { Compras } \\
(\%)\end{array}$ & $\begin{array}{l}\text { Autonomia } \\
\text { de compras }\end{array}$ \\
\hline 9 & Leite de vaca e de outros animais & $47,0 \%$ & $79,6 \%$ \\
\hline 23 & Leite resfriado, esterilizado e pasteurizado & $20,4 \%$ & $100,0 \%$ \\
\hline 74 & Comércio & $12,2 \%$ & $97,9 \%$ \\
\hline 75 & Transporte, armazenagem e correios & $4,1 \%$ & $98,0 \%$ \\
\hline 81 & Serviços prestados às empresas & $3,1 \%$ & $98,0 \%$ \\
\hline 28 & Produtos das usinas e do refino de açúcar & $1,7 \%$ & $35,2 \%$ \\
\hline 26 & Farinha de trigo e derivados & $1,5 \%$ & $34,6 \%$ \\
\hline \multirow[t]{2}{*}{43} & Produtos químicos inorgânicos & $1,2 \%$ & $88,2 \%$ \\
\hline & Produção e distribuição de eletricidade, gás, água, esgoto e & & \\
\hline 72 & limpeza urbana & $1,2 \%$ & $99,5 \%$ \\
\hline 59 & Produtos de metal - exclusive máquinas e equipamento & $1,1 \%$ & $90,8 \%$ \\
\hline 76 & Serviços de informação & $0,8 \%$ & $98,6 \%$ \\
\hline 41 & Outros produtos do refino de petróleo e coque & $0,7 \%$ & $81,9 \%$ \\
\hline 31 & Bebidas & $0,6 \%$ & $35,9 \%$ \\
\hline 78 & Atividades imobiliárias e aluguéis & $0,5 \%$ & $94,7 \%$ \\
\hline 30 & Outros produtos alimentares & $0,5 \%$ & $35,1 \%$ \\
\hline 27 & Óleos de milho, amidos e féculas vegetais e rações & $0,5 \%$ & $35,3 \%$ \\
\hline 60 & Máquinas e equipamentos, inclusive manutenção e reparos & $0,4 \%$ & $90,7 \%$ \\
\hline 77 & Intermediação financeira, seguros e previdência complementar & $0,3 \%$ & $98,4 \%$ \\
\hline 52 & Artigos de plástico & $0,3 \%$ & $96,4 \%$ \\
\hline 54 & Outros produtos de minerais não metálicos & $0,3 \%$ & $76,4 \%$ \\
\hline 63 & Máquinas, aparelhos e materiais elétricos & $0,2 \%$ & $92,2 \%$ \\
\hline 50 & Produtos e preparados químicos diversos & $0,1 \%$ & $86,5 \%$ \\
\hline 39 & Papel e papelão, embalagens e artefatos & $0,1 \%$ & $66,2 \%$ \\
\hline 79 & Serviços de manutenção e reparação & $0,1 \%$ & $96,8 \%$ \\
\hline 47 & Defensivos agrícolas & $0,1 \%$ & $89,3 \%$ \\
\hline 44 & Produtos químicos orgânicos & $0,1 \%$ & $87,1 \%$ \\
\hline 56 & Semiacabados, laminados planos, longos e tubos de aço & $0,1 \%$ & $70,1 \%$ \\
\hline 73 & Construção civil & $0,1 \%$ & $83,8 \%$ \\
\hline 80 & Serviços de alojamento e alimentação & $0,1 \%$ & $89,5 \%$ \\
\hline 68 & Peças e acessórios para veículos automotores & $0,1 \%$ & $94,4 \%$ \\
\hline \multirow[t]{2}{*}{83} & Serviços prestados às famílias e associativos & $0,1 \%$ & $88,4 \%$ \\
\hline & TOTAL & $100,0 \%$ & $85,4 \%$ \\
\hline
\end{tabular}

Fonte: Dados da pesquisa. 
Sexto agrupamento: Por fim, apresenta-se, na Tabela 7, a composição setorial das compras intermediárias de insumos estaduais realizadas pelo setor de Produtos do laticínio e sorvetes, de modo que o grau de autonomia seja de $100 \%$. Observa-se que os 34 setores envolvidos na industrialização do leite são praticamente os mesmos envolvidos no agrupamento anterior que analisou o leite resfriado e pasteurizado.

A análise do primeiro agrupamento (Tabela 2) mostrou que o setor de Produtos de laticínios adquiriu, em 2008, 22,1 \% do setor de Leite de vacas e de outros animais; 9,6\% do setor de Leite resfriado; e 20,8 \% das compras intermediárias fornecidas pelo próprio setor, totalizando 52,5\% indicando que existem ainda $48,5 \%$ de insumos diretos que são fornecidos por outros setores da economia mineira. A Tabela 7 mostra que, dentre os demais setores, os mais importantes, destaca-se "Comércio" (16,6 \%) e "Transporte, armazenagem e correios" (5,5\%), e "Serviços prestados às empresas" $(4,0 \%)$, setores ligados à distribuição da produção.

A Figura 3 mostra o fluxo de relacionamentos intersetoriais obtidos a partir do quarto, quinto e sexto agrupamentos. As setas que chegam aos setores centrais mostram os percentuais de gastos em relação ao total de gasto em insumos intermediários produzidos dentro do estado de Minas Gerais, de forma que o total dos gastos para cada setor central seja $100 \%$.

Observa-se que o setor de "Leite de vaca e de outros animais" compra 3,5\% dos seus insumos no próprio setor; sendo $17,6 \%$ de seus insumos oriundos dos setores agricultura e pecuária, $26,5 \%$ da indústria de alimentos (basicamente ração) e $36,3 \%$ dos demais setores. O setor de "Leite resfriado, esterilizado e pasteurizado" adquire $20,4 \%$ de seus insumos no próprio setor, sendo $47,0 \%$ adquiridos do setor de "Leite de vaca e de outros animais", 4,8 \% do setor indústria de alimentos, e o restante, $27,8 \%$ é oriundo dos demais setores da economia. O setor de "Produtos de laticínios e sorvete" adquire $20,8 \%$ de seus insumos no próprio setor, sendo $22,1 \%$ adquiridos do setor de "Leite de vaca e de outros animais"; 9,6 \% do setor de "Leite resfriado, esterilizado e pasteurizado"; $8,0 \%$ do setor indústria de alimentos; e o restante, $39,5 \%$, é oriundo dos demais setores da economia.

Tabela 7 - Análise do perfil coluna do setor "Produtos do laticínio e sorvetes"

\begin{tabular}{cccc}
\hline No & SETORES & $\begin{array}{c}\text { Compra } \\
\mathrm{s}(\%)\end{array}$ & $\begin{array}{c}\text { Autonomia } \\
\text { de compras }\end{array}$ \\
\hline 9 & Leite de vaca e de outros animais & $22,1 \%$ & $80,1 \%$ \\
24 & Produtos do laticínio e sorvetes & $20,8 \%$ & $100,0 \%$ \\
74 & Comércio & $16,6 \%$ & $98,1 \%$ \\
23 & $9,6 \%$ & $100,0 \%$ \\
75 & Leite resfriado, esterilizado e pasteurizado & $5,5 \%$ & $98,9 \%$ \\
81 & Transporte, armazenagem e correios & $4,0 \%$ & $98,7 \%$ \\
& Serviços prestados às empresas & & Continua
\end{tabular}




\section{Continuação}

72

59

41

76

78

31

30

60

77

52

54

63

47

50

79

39

44

56

73

80

83

68

45

40
Produtos químicos inorgânicos

Óleos de milho, amidos e féculas vegetais e rações

Produtos das usinas e do refino de açúcar

Farinha de trigo e derivados

Produção e distribuição de eletricidade, gás, água, esgoto e limpeza urbana

Produtos de metal - exclusive máquinas e equipamento

Outros produtos do refino de petróleo e coque

Serviços de informação

Atividades imobiliárias e aluguéis

Bebidas

Outros produtos alimentares

Máquinas e equipamentos, inclusive manutenção e reparos

Intermediação financeira, seguros e previdência complementar Artigos de plástico

Outros produtos de minerais não metálicos

Máquinas, aparelhos e materiais elétricos

Defensivos agrícolas

Produtos e preparados químicos diversos

Serviços de manutenção e reparação

Papel e papelão, embalagens e artefatos

Produtos químicos orgânicos

Semiacabados, laminados planos, longos e tubos de aço

Construção civil

Serviços de alojamento e alimentação

Serviços prestados às famílias e associativos

Peças e acessórios para veículos automotores

Fabricação de resina e elastômeros

Jornais, revistas, discos e outros produtos gravados
$2,4 \% \quad 88,5 \%$

$2,3 \% \quad 35,4 \%$

$2,2 \% \quad 35,3 \%$

$1,9 \% \quad 34,7 \%$

$1,9 \% \quad 99,9 \%$

$1,5 \% \quad 95,3 \%$

$1,4 \% \quad 82,0 \%$

$1,4 \% \quad 98,7 \%$

$0,9 \% \quad 95,5 \%$

$0,8 \% \quad 36,0 \%$

$0,8 \% \quad 35,2 \%$

$0,6 \% \quad 95,7 \%$

$0,5 \% \quad 99,3 \%$

$0,5 \% \quad 97,2 \%$

$0,4 \% \quad 77,8 \%$

$0,3 \% \quad 96,7 \%$

$0,2 \% \quad 89,5 \%$

$0,2 \% \quad 86,9 \%$

$0,2 \% \quad 97,3 \%$

$0,1 \% \quad 66,5 \%$

$0,1 \% \quad 87,6 \%$

$0,1 \% \quad 71,0 \%$

$0,1 \% \quad 87,0 \%$

$0,1 \% \quad 89,6 \%$

$0,1 \% \quad 89,8 \%$

$0,1 \% \quad 96,1 \%$

$0,1 \% \quad 88,5 \%$

$0,1 \% \quad 98,9 \%$

$100,0 \% \quad 87,8 \%$

Fonte: Dados da pesquisa. 
Figura 3 - Decomposição das transações intermediárias do complexo lácteo mineiro 2008

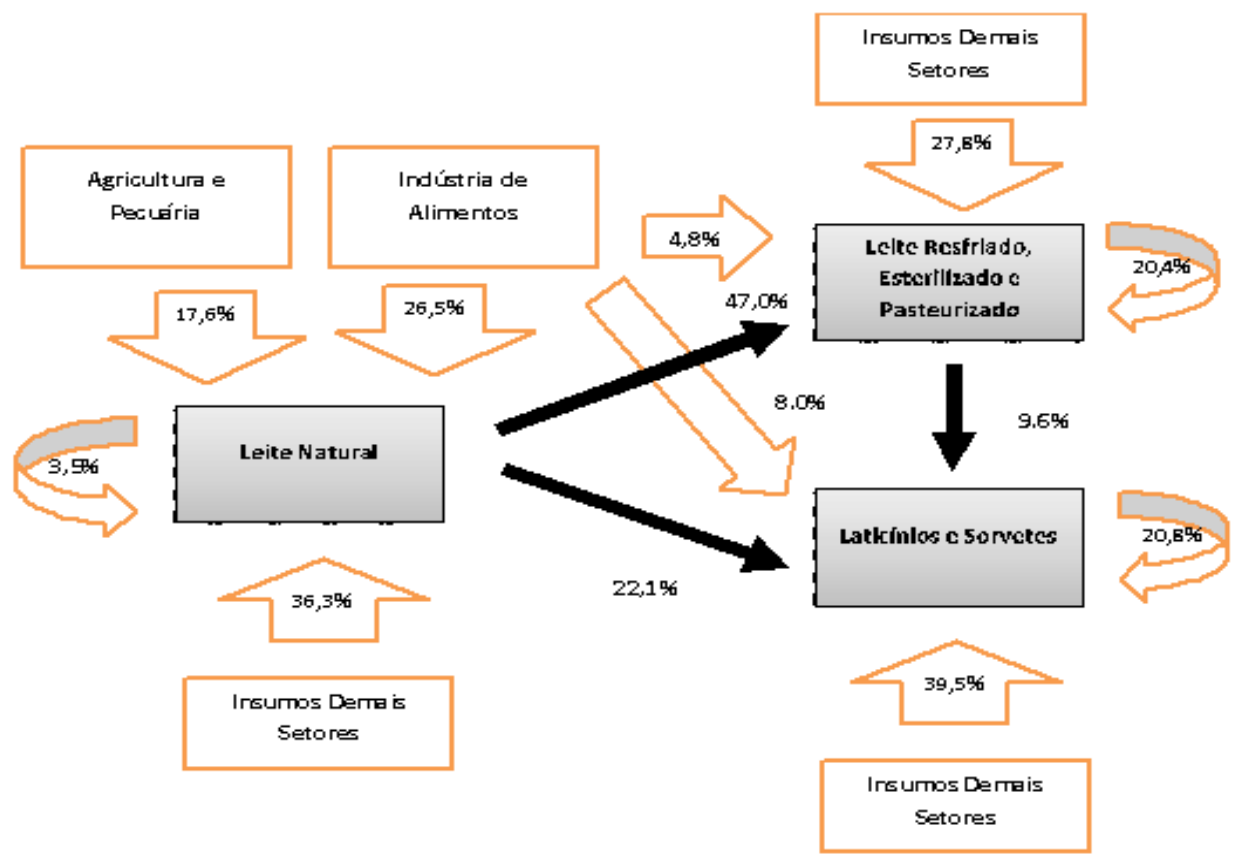

Fonte: Elaborado com base nas Tabelas 5, 6, 7 e na MIP 2008.

Em razão do elevado nível de agregação da MIP de Minas Gerais, não é possível identificar de forma pormenorizada os insumos utilizados em seus processos produtivos (por exemplo, açúcares e frutas utilizados na fabricação de iogurte) e sim os setores que fornecem esses insumos. Também, dado o processo de transformação dos dados para criar uma matriz de insumo-produto no tipo produto-produto, a expansão de uma base setorial 40 setores, para uma base de produtos ( 85 produtos) distorce os dados quando se quer verificar as transações de compras para um produto específico. São necessários alguns ajustes nesses valores, o que depende do conhecimento e do tempo de pesquisa dos analistas com especialistas e profissionais dentro do setor lácteo e de pesquisas complementares. De qualquer forma, pode-se afirmar que ficam bem caracterizadas as articulações intersetoriais que se desenvolvem na economia mineira em torno da produção de leite natural, bem como o processo de valor de geração de valor adicionado entre os três setores principais desse agrupamento. 


\section{Dinâmica e decomposição do crescimento da cadeia láctea mineira - $2005 / 2008$}

As Tabelas 8 e 9 mostram os valores da demanda intermediária e final do setor "Leite de vaca e de outros animais" e do setor "Leite, produtos de laticínios e sorvetes" elaboradas com base nas matrizes de insumo-produto de Minas Gerais para os anos de 2005 e 2008. Em 2008, o setor "Leite, produtos de laticínios e sorvetes" foi desagregado em dois: "Leite resfriado, esterilizado e pasteurizado" e "Produtos de laticínios e sorvetes". Para a análise comparativa manteve-se o nível de menor agregação. Os valores monetários de 2005 estão a preços de 2008, corrigidos pelo deflator do valor adicionado bruto, fornecidos pela FJP.

Observe que o valor bruto da produção do setor de Leite de vaca e de outros animais, subdividido em consumo intermediário e final, aumentou $18,9 \%$ entre 2005 e 2008, passando de 4,4 bilhões de reais para 5,3 bilhões de reais. Note-se que, como dito anteriormente, em 2005, o leite natural produzido no estado de Minas Gerais ou era vendido para a demanda intermediária - quase a totalidade $(94,4 \%)$, ou era vendido para o consumo final das famílias $-5,6 \%$ do total da produção. Já em 2008, houve uma grande mudança estrutural na demanda desse setor e apenas 25,2 \% foi vendido para a demanda intermediária, e o restante para a demanda final, sendo que $66,7 \%$ foi exportado para outros estados do país e $8,2 \%$ foi vendido para o consumo das famílias. Assim, houve uma redução da demanda intermediária do setor de "Leite de vaca e de outros animais" em $68 \%$ entre 2005 e 2008 (passando de 4,2 bilhões de reais para 1,3 bilhão de reais). Em contrapartida, a demanda final aumentou 1.484,6 \% neste período.

Tabela 8 - Demanda intermediária e final dos setores centrais da cadeia láctea mineira $-2005$

\begin{tabular}{|c|c|c|c|c|c|c|c|c|c|c|}
\hline 2005 & $\begin{array}{c}\text { Leite de vaca } \\
\text { e de outros } \\
\text { animais }\end{array}$ & $\begin{array}{l}\text { Leite, } \\
\text { produtos do } \\
\text { laticínios e } \\
\text { sorvetes }\end{array}$ & Demais setores & $\begin{array}{c}\text { Consumo } \\
\text { Intermediário }\end{array}$ & $\begin{array}{l}\text { Exportações de } \\
\text { bens e serviços } \\
\text { internacionais }\end{array}$ & $\begin{array}{c}\text { Exportações de } \\
\text { bens e serviços } \\
\text { interestaduais }\end{array}$ & $\begin{array}{c}\text { Consumo } \\
\text { das famílias }\end{array}$ & $\begin{array}{c}\text { Variação } \\
\text { de estoque }\end{array}$ & $\begin{array}{l}\text { Demanda } \\
\text { final }\end{array}$ & $\begin{array}{c}\text { Demanda } \\
\text { Total ou } \\
\text { VBP }\end{array}$ \\
\hline $\begin{array}{l}\text { Leite de vaca e de } \\
\text { outros animais }\end{array}$ & 50 & 4.169 & & 4.219 & & & 251 & & 251 & 4.470 \\
\hline \multirow[t]{2}{*}{$\begin{array}{l}\text { Leite, produtos do } \\
\text { laticínios e sorvetes }\end{array}$} & & 424 & 313 & 737 & 65 & 3.996 & 2.784 & 217 & 7.062 & 7.799 \\
\hline & & & & Total & 65 & 3.996 & 3.035 & 217 & 7.313 & \\
\hline
\end{tabular}

Fonte: MIP 2005, valores em milhões de reais a preços de 2008. 
Tabela 9 - Demanda intermediária e final dos setores centrais da cadeia láctea mineira $-2008$

\begin{tabular}{|c|c|c|c|c|c|c|c|c|c|c|}
\hline 2008 & $\begin{array}{l}\text { Leite de vaca } \\
\text { e de outros } \\
\text { animais }\end{array}$ & $\begin{array}{l}\text { Leite, } \\
\text { produtos do } \\
\text { laticínios e } \\
\text { sorvetes }\end{array}$ & Demais setores & $\begin{array}{c}\text { Consumo } \\
\text { Intermediário }\end{array}$ & $\begin{array}{c}\text { Exportações de } \\
\text { bens e serviços } \\
\text { internacionais }\end{array}$ & $\begin{array}{c}\text { Exportações de } \\
\text { bens e serviços } \\
\text { interestaduais }\end{array}$ & $\begin{array}{l}\text { Consumo } \\
\text { das famílias }\end{array}$ & $\begin{array}{c}\text { Variação } \\
\text { de estoque }\end{array}$ & $\begin{array}{l}\text { Demanda } \\
\text { final }\end{array}$ & $\begin{array}{c}\text { Demanda } \\
\text { Total ou } \\
\text { VBP }\end{array}$ \\
\hline $\begin{array}{c}\text { Leite de vaca e de } \\
\text { outros animais }\end{array}$ & 49 & 1.289 & & 1.338 & & 3.542 & 434 & & 3.976 & 5.314 \\
\hline \multirow[t]{2}{*}{$\begin{array}{l}\text { Leite, produtos do } \\
\text { laticínios e sorvetes }\end{array}$} & & 1.212 & 972 & 2.184 & 359 & 4.660 & 2.632 & 55 & 7.706 & 9.890 \\
\hline & & & & Total & 359 & 8.202 & 3.066 & 55 & 11.682 & \\
\hline
\end{tabular}

Fonte: MIP 2008, valores em milhões de reais a preços de 2008.

No que refere ao setor de "Leite, produtos de laticínios e sorvetes", o segmento teve, entre 2005 e 2008, um crescimento real na demanda intermediária de 196,3\% e um crescimento na demanda final de apenas $9,1 \%$. A produção, como um todo (VBP), apresentou um crescimento real de $26,8 \%$ no período. Em 2005, apenas $9,5 \%$ da produção deste eram vendidos para a demanda intermediária e o restante, 90,5\%, era vendido para a demanda final. Em 2008, a demanda intermediária absorveu 22,1\% e a demanda final absorveu $77,9 \%$. Percebe-se que nesse período avançou a interação entre as empresas do setor "Leite, produtos de laticínios e sorvetes", em que a venda intermediária passou de 424 milhões de reais em 2005 para 1,2 bilhões de reais em 2008 , um aumento de $185,7 \%$ no período. Pode-se dizer que houve um aumento do processamento intermediário feito entre as empresas muito em virtude da exigência de um maior controle de qualidade pela cadeia produtiva. Verifica-se que houve um aumento de 450,4\% das exportações internacionais (3,6 \% da produção de 2008), um aumento de $16,6 \%$ das exportações interestaduais (47,1 \% da produção de 2008$)$ e uma redução de $5,5 \%$ do consumo das famílias (26,6 \% da produção de 2008$)$.

A Tabela 10 mostra a contribuição ao crescimento da demanda final, em pontos percentuais, de cada um dos seus componentes formadores, dos setores de "Leite de vaca e de outros animais" e "Leite, produtos de laticínios e sorvetes". No agregado, a demanda final, em termos reais, desses dois setores, aumentou 59,7\% no período, passando de 7,3 bilhões de reais em 2005 para 11,7 bilhões em 2008. As exportações internacionais contribuíram com 4 pontos percentuais, as exportações interestaduais com 57,5 pontos percentuais, o consumo das famílias com apenas 0,4 pontos percentuais e o estoque contribuiu negativamente com 2,2 pontos percentuais (se consumiu o estoque do ano anterior). Interessante observar que, do aumento de $1484,6 \%$ observado na demanda final de leite de vaca no período, 1.411,6 pontos são em razão das exportações interestaduais que antes não existiam e 73 pontos percentuais ao aumento do consumo das famílias mineiras. 
Tabela 10 - Contribuição ao crescimento da demanda final do complexo lácteo mineiro entre 2005 e 2008, em pontos percentuais

\begin{tabular}{|c|c|c|c|c|c|}
\hline & $\begin{array}{c}\text { Exportações de } \\
\text { bens e serviços } \\
\text { internacionais } \\
(1)\end{array}$ & $\begin{array}{c}\text { Exportações de } \\
\text { bens e serviços } \\
\text { interestaduais } \\
(2)\end{array}$ & $\begin{array}{c}\text { Consumo } \\
\text { das } \\
\text { famílias } \\
(3)\end{array}$ & $\begin{array}{c}\text { Variação estoque } \\
(4)\end{array}$ & $\begin{array}{c}\text { Demanda } \\
\text { final } \\
(5)= \\
(1)+(2)+(3)+ \\
(4)\end{array}$ \\
\hline $\begin{array}{c}\text { Leite de vaca e de } \\
\text { outros animais }\end{array}$ & $0,0 \%$ & $1.411,6 \%$ & $73,0 \%$ & $0,0 \%$ & $1.484,6 \%$ \\
\hline $\begin{array}{c}\text { Leite, produtos do } \\
\text { laticínios e sorvetes }\end{array}$ & $4,2 \%$ & $9,4 \%$ & $-2,2 \%$ & $-2,3 \%$ & $9,1 \%$ \\
\hline Total & $4,0 \%$ & $57,5 \%$ & $0,4 \%$ & $-2,2 \%$ & $59,7 \%$ \\
\hline
\end{tabular}

Fonte: Elaborado com base nas Tabelas 8 e 9 .

A Tabela 11 mostra a contribuição ao crescimento do Valor Bruto da Produção (VBP), em pontos percentuais, de cada um dos seus componentes formadores, dos setores de "Leite de vaca e de outros animais" e "Leite, produtos de laticínios e sorvetes".

Tabela 11 - Contribuição ao crescimento do Valor Bruto da Produção do complexo lácteo mineiro entre 2005 e 2008 , em pontos percentuais

\begin{tabular}{|c|c|c|c|c|c|c|c|}
\cline { 2 - 8 } \multicolumn{1}{c|}{} & $\begin{array}{c}\text { Consumo } \\
\text { intermediário } \\
(1)\end{array}$ & $\begin{array}{c}\text { Exportações } \\
\text { de bens e } \\
\text { serviços } \\
\text { internacionais } \\
(2)\end{array}$ & $\begin{array}{c}\text { Exportações } \\
\text { de bens e } \\
\text { serviços } \\
\text { interestaduais } \\
(3)\end{array}$ & $\begin{array}{c}\text { Consumo } \\
\text { das } \\
\text { famílias } \\
(4)\end{array}$ & $\begin{array}{c}\text { Variação } \\
\text { de } \\
\text { estoque } \\
(5)\end{array}$ & $\begin{array}{c}\text { Demanda } \\
\text { final } \\
(6)= \\
(2)+(3)+(4) \\
+(5)\end{array}$ & $\begin{array}{c}\text { Demanda } \\
\text { Total ou } \\
\text { VBP } \\
(1)+(6)\end{array}$ \\
\hline $\begin{array}{c}\text { Leite de } \\
\text { vaca e de } \\
\text { outros } \\
\text { animais }\end{array}$ & $-64,5 \%$ & $0,0 \%$ & $79,2 \%$ & $4,1 \%$ & $0,0 \%$ & $83,3 \%$ & $18,9 \%$ \\
\hline $\begin{array}{c}\text { Leite, } \\
\text { produtos } \\
\text { do laticínios } \\
\text { e sorvetes }\end{array}$ & $18,6 \%$ & $3,8 \%$ & $8,5 \%$ & $-1,9 \%$ & $-2,1 \%$ & $8,3 \%$ & $26,8 \%$ \\
\hline Total & $-11,7 \%$ & $2,4 \%$ & $34,3 \%$ & $0,3 \%$ & $-1,3 \%$ & $35,6 \%$ & $23,9 \%$ \\
\hline
\end{tabular}

Fonte: Elaborado com base nas Tabelas 8 e 9.

No agregado, o VBP, em termos reais, desses dois setores, aumentou 23,9\% no período passando de 12,2 bilhões de reais em 2005 para 15,2 bilhões em 2008.

A produção de "Leite de vaca e de outros animais" aumentou $18,9 \%$, sendo que o consumo intermediário caiu 64,5 pontos percentuais comparados ao volume 
produzido em 2005 e as exportações aumentaram 79,2 pontos percentuais e o consumo das famílias 4,1 pontos percentuais. Essa queda no consumo intermediário, mais do que ganhos de eficiência obtidos pelo setor de laticínios, é explicada pelo aumento do volume de exportações desse insumo básico para outros estados.

A produção de "Leite, produtos de laticínios e sorvetes" aumentou 26,8 \%, sendo 18,6 pontos percentuais explicados pelo aumento do consumo intermediário e 8,3 pontos percentuais explicados pelo aumento da demanda final. Esse aumento de $8,3 \%$ na demanda final é explicado pelo aumento de 3,8 pontos percentuais nas exportações internacionais, pelo aumento de 8,5 pontos percentuais das exportações interestaduais, pressionado pela queda de 1,9 pontos percentuais no consumo das famílias e na queda de 2,3 pontos percentuais no nível dos estoques (se consumiu o estoque do ano anterior).

\section{Conclusões}

O artigo teve como objetivo identificar os agrupamentos e as atividades interrelacionadas com o complexo lácteo, com fim de avaliar as articulações que se estendem para outros setores provedores de insumos e de outras indústrias que utilizam a produção de leite natural e a produção da indústria láctea como insumos.

Como resultado, verificou-se que, em 2008, 66, 7\% da produção de "Leite de vaca e de outros animais" do estado de Minas Gerais foi destinado às exportações interestaduais e somente $25,2 \%$ para a demanda intermediária. O setor de "Leste resfriado, esterilizado e pasteurizado" destinou 40,1 \% de sua produção para a demanda intermediária e 59,9\% para a demanda final (44,0\% para o consumo das famílias e $15,5 \%$ para a exportação interestadual). A indústria láctea, por sua vez, é fundamentalmente produtora de bens finais, apresentando um mínimo de interligações com outras indústrias alimentícias ( $8,4 \%$ da sua produção). O destino da produção da indústria láctea para o consumo das famílias foi de $21,7 \%$ e o maior volume destinado para as exportações interestaduais $(56,0 \%)$ e internacionais $(4,6$ $\%)$. Ou seja, a cadeia láctea mineira é exportadora líquida para outros estados brasileiros, o que deixa em evidência as vantagens comparativas e competitivas de Minas Gerais nesse mercado.

Esses três setores, considerados centrais, possuem um grau de autonomia de vendas intermediárias global de $72,4 \%$ e de autonomia de compras intermediárias global de 52,5\%, e, portanto, se apresentam como um agrupamento produtivo com um nível elevado de autonomia no suprimento de insumos.

Os fluxos de relacionamentos intersetoriais obtidos a partir do quarto, quinto e sexto agrupamentos revelam que o setor de "Leite de vaca e de outros animais" compra $17,6 \%$ de seus insumos oriundos dos setores agricultura e pecuária, 26,5\% da 
indústria de alimentos (basicamente ração) e aproximadamente $36,3 \%$ de outros setores dentre os quais aqueles que são difundidos pelo sistema econômico (combustíveis, comércio, transporte etc.).

O setor de "Leite resfriado, esterilizado e pasteurizado" adquire $20,4 \%$ de seus insumos no próprio setor, sendo $47,0 \%$ adquiridos do setor de "Leite de vaca e de outros animais", 4,8\% do setor indústria de alimentos, e o restante, $27,8 \%$, é oriundo dos demais setores da economia.

O setor de "Produtos de laticínios e sorvete" adquire 20,8\% de seus insumos no próprio setor, sendo $22,1 \%$ adquiridos do setor de "Leite de vaca e de outros animais"; 9,6 \% do setor de "Leite resfriado, esterilizado e pasteurizado"; $8,0 \%$ do setor Indústria de alimentos; e o restante, $39,5 \%$, é oriundo dos demais setores da economia.

Por meio da relação Valor Adicionado/Valor Bruto da Produção, fica evidente que, em termos relativos, o setor "Leite de vaca e de outros animais" adiciona mais valor do que a indústria de "Leite resfriado, esterilizado e pasteurizado" e "Produtos de laticínios e sorvetes", representados pelos índices de 60,0\%, 23,0 \% e 41,6 \% do valor bruto da produção, respectivamente. Esses coeficientes de valor adicionado são maiores, mas próximos da média observada para o setor "Pecuária e pesca" e demais indústrias de "Alimentos e bebidas" do estado, que são de $57,7 \%$ e de $17,4 \%$ do valor bruto da produção, respectivamente.

Avaliando a mudança estrutural da demanda final entre os anos de 2005 e 2008 para os setores "Leite de vaca e de outros animais" e "Leite, produtos de laticínios e sorvetes", verificou-se que, em termos reais, a demanda final aumentou 59,7 \% no período, sendo que as exportações internacionais contribuíram com 4 pontos percentuais, as exportações interestaduais com 57,5 pontos percentuais, o consumo das famílias com apenas 0,4 pontos percentuais e o estoque contribuiu negativamente com 2,3 pontos percentuais (se consumiu o estoque do ano anterior). Observou-se ainda um aumento de 1.484,6 \% na demanda final do setor "Leite de vaca e de outros animais" no período, sendo 1.411,6 pontos percentuais em razão das exportações interestaduais que antes não existiam e 73 pontos percentuais por causa do aumento do consumo das famílias mineiras.

A principal contribuição desta pesquisa foi fornecer um conjunto de informações do complexo lácteo mineiro que é fortemente integrado ao sistema econômico como um todo, permitindo visualizar o fluxo de insumos e de bens finais por origem e destino, bem como a dimensão econômica e os alcances que têm o complexo lácteo mineiro.

Vale salientar que se deve ampliar o estudo e as comparações entre cadeias produtivas regionais em diferentes pontos no tempo e entre diferentes estados brasileiros, de forma a entender a dinâmica dentro do território nacional. Os 
complexos produtivos que conseguirem maior harmonia entre seus componentes levarão vantagens na competição internacional. As trocas de insumos e informações entre as cadeias produtivas nacionais poderão fortalecer a competição dos produtores nacionais a frente de outros países do mundo.

O grande desafio do complexo lácteo mineiro e brasileiro é atingir os mercados internacionais em grandes proporções. O desenvolvimento econômico acelerado em uma região rica em recursos naturais dependerá da rapidez com que esta aprenda a industrializar e a processar seus recursos naturais, assim como a desenvolver as atividades provedoras de insumos, serviços de engenharia e equipamentos para essas atividades.

\section{Referências}

ALMEIDA, T. R. C. et. ali. Evolução da estrutura produtiva de Minas Gerais: uma análise do comportamento da agropecuária e indústria estadual com ênfase na década (2000-2010). In: Ideias em desenvolvimento: políticas para a promoção do avanço econômico em Minas Gerais. Belo Horizonte. Fundação João Pinheiro, 2014.

ARAÚJO, N. B. et. alli. Complexo agroindustrial. "O Agribusiness Brasileiro". São Paulo. Dez.1990. 228 p.

DAVIS, J. \& GOLDBERG, R. A concept of agribusiness. Boston: Harvard University, 1957.

FUNDAÇÃO JOÃO PINHEIRO. Matriz de insumo-produto de Minas Gerais 2005 e 2008. Disponível em: http://fjp.mg.gov.br/index.php/produtos-e-servicos1/2737tabela-de-recursos-e-usos-tru-mg-e-matriz-insumo-produto

FINAMORE, E. B.; MONTOYA, M. A. Dimensão econômica do complexo lácteo gaúcho. Revista de Economia e Agronegócio, Viçosa - MG, v. 3, n.2, p. 213-249, 2005.

FINAMORE, E. B.; GOMES, A. P. Delimitação e grau de autonomia do complexo lácteo de Minas Gerais. In: $54^{\circ}$ Congresso da Sociedade Brasileira de Economia, Administração e Sociologia e Rural (SOBER), 2016, Maceió, AL. Desenvolvimento, território e biodiversidade, 2016.

FURTUOSO, M. O produto interno bruto do complexo agroindustrial brasileiro. Tese (Doutorado) - Esalq/USP, 1998. 
GOMES, S. T. Economia da Produção do Leite. Belo Horizonte, 2000.

LAUSCHNER, R. Agribusiness, cooperativa e produtor rural. São Leopoldo: Unisinos, 1993. 296 p.

LEONTIEF, W. The structure of the american economy in 1951. Ed. Ampl., New York: Oxford University Press, 1951.

MONTOYA, M. A.; FINAMORE, E. B. Delimitação e encadeamento de sistemas agroindustriais: o caso do complexo lácteo do Rio Grande do Sul. Revista de Economia Aplicada, 2005. DOI: https://doi.org/10.1590/S1413-80502005000400008

PRODUÇÃO DA PECUÁRIA MUNICIPAL / IBGE. - Rio de Janeiro: IBGE, 1974-2016 v. 44, p.1-51, 2016.

RAMOS, R. L. O. Metodologia para o cálculo de coeficientes técnicos diretos em um modelo de insumo-produto. Texto para discussão, Rio de Janeiro. n. 83. IBGE, 1996, p.94

RAMOS, J. Uma estratégia de desarrollo a partir de complejos productivos em torno a los recursos naturales. Revista de la Cepal, v.66. p.105 a 125. 1998. DOI: https://doi.org/10.18356/1afc17e9-es

VAILLANT, M. El complexo productivo lácteo del Uruguay. In: Apertura economica $y$ (des)encadeamentos productivos. Cepal, 1999. p. 263 a 314.

Recebido em 24.05.18

Aprovado em 09.01.19 
Anexo 1 - Matriz de insumo-produto e grau de autonomia do primeiro agrupamento produtivo do complexo lácteo mineiro -2008

\begin{tabular}{|c|c|c|c|c|c|c|c|c|c|c|c|c|c|}
\hline \begin{tabular}{|c} 
SETORES \\
\end{tabular} & $\begin{array}{c}\text { Leite de } \\
\text { vaca e de } \\
\text { outros } \\
\text { animais }\end{array}$ & $\begin{array}{c}\text { Leite } \\
\text { resfriado, } \\
\text { esterilizado } \\
\mathrm{e} \\
\text { pasteurizado }\end{array}$ & $\begin{array}{c}\text { Produtos } \\
\text { do laticínio } \\
\text { e sorvetes }\end{array}$ & $\begin{array}{c}\text { CONSUMO } \\
\text { INTERMEDIÁRIO }\end{array}$ & $\begin{array}{c}\text { Exportação } \\
\text { internacional de } \\
\text { bens }\end{array}$ & $\begin{array}{c}\text { Exportação } \\
\text { interestadual } \\
\text { de bens }\end{array}$ & $\begin{array}{c}\text { Consumo } \\
\text { da } \\
\text { administração } \\
\text { pública }\end{array}$ & $\begin{array}{l}\text { Consumo } \\
\text { das } \\
\text { ISFLSF }\end{array}$ & $\begin{array}{c}\text { Consumo } \\
\text { das familias }\end{array}$ & $\begin{array}{c}\text { Formação } \\
\text { bruta } \\
\text { de capital fixo }\end{array}$ & $\begin{array}{l}\text { Variação } \\
\text { de estoque }\end{array}$ & $\begin{array}{c}\text { Demanda } \\
\text { final }\end{array}$ & $\begin{array}{c}\text { Demanda } \\
\text { total }\end{array}$ \\
\hline 9-Leite de vaca e de outros animais & 49 & 597 & 692 & $\begin{array}{r}1.338 \\
\end{array}$ & -9 & 3.542 & - & - & 434 & - & - & 3.976 & 5.314 \\
\hline 23 - Leite resfriado, esterilizado e pasteurizado & - & 260 & 301 & 869 & 0 & 335 & - & - & 953 & - & 9 & 1.297 & 2.167 \\
\hline 24 - Produtos do laticínio e sorvetes & & & 651 & 1.315 & 359 & 4.325 & - & - & 1.679 & - & 46 & $\begin{array}{r}6.409 \\
14092\end{array}$ & 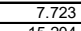 \\
\hline Insumos estaduais & 1.410 & 1.271 & 3.133 & 5.814 & 359 & 8.202 & - & & 3.066 & - & 55 & 11.682 & 15.204 \\
\hline $\begin{array}{r}\text { IMPORTACAAO } \\
\end{array}$ & 591 & 338 & 1.174 & 2.103 & & & & & & & & & \\
\hline $\begin{array}{c}\text { IMPOSTOS SOBRE PRODUÇAOO E PRODUTOS } \\
\text { Importaçăo + Impostos }\end{array}$ & $\begin{array}{l}124 \\
714\end{array}$ & $\begin{array}{r}58 \\
397 \\
\end{array}$ & $\begin{array}{r}206 \\
1.380 \\
\end{array}$ & $\begin{array}{r}388 \\
2.491 \\
\end{array}$ & & & & & & & & & \\
\hline Insumos estaduais + importados + impostos & 2.124 & 1.668 & 4.512 & 8.305 & & & & & & & & & \\
\hline SUBTOTAL (3) - Valor adicionado bruto (PIB) & 3.189 & 498 & 3.211 & 6.899 & & & & & & & & & \\
\hline VALOR BRUTO DA PRODUÇÃO & 5.314 & 2.167 & 7.723 & 15.204 & & & & & & & & & \\
\hline Fator trabalho (ocupaçöes) & 296.000 & 15.069 & 89.362 & 400.431 & & & & & & & & & \\
\hline SETORES & $\begin{array}{l}\text { Leite de } \\
\text { vaca e de } \\
\text { outros } \\
\text { animais }\end{array}$ & $\begin{array}{l}\text { Leite resfriado, } \\
\text { esterilizado e } \\
\text { pasteurizado }\end{array}$ & $\begin{array}{c}\text { Produtos do } \\
\text { laticinio e } \\
\text { sorvetes }\end{array}$ & $\begin{array}{l}\text { AUTONOMIA DE } \\
\text { VENDAS }\end{array}$ & VI/VBP & & & & & & & & \\
\hline $\begin{array}{l}\text { Leite de vaca e de outros animais } \\
\end{array}$ & $3,6 \%$ & $44,6 \%$ & $51,7 \%$ & $100,0 \%$ & $25,2 \%$ & & & & & & & & \\
\hline Leite resfriado, esterilizado e paste urizado & $0,0 \%$ & $29,9 \%$ & $34,7 \%$ & $64,6 \%$ & $40,1 \%$ & & & & & & & & \\
\hline Produtos do laticinio e sorvetes & $0,0 \%$ & $0,0 \%$ & $49,5 \%$ & $49,5 \%$ & $17,0 \%$ & & & & & & & & \\
\hline
\end{tabular}

\begin{tabular}{|c|c|c|c|c|}
\hline SETORES & $\begin{array}{c}\text { Leite de } \\
\text { vaca e de } \\
\text { outros } \\
\text { animais }\end{array}$ & $\begin{array}{c}\text { Leite re sfriado, } \\
\text { esterilizado } \\
\text { pasteurizado }\end{array}$ & $\begin{array}{c}\text { Produtos do } \\
\text { laticinio } e \\
\text { sorvetes }\end{array}$ & Total \\
\hline Leite de vaca e de outros animais & $3,5 \%$ & $47,0 \%$ & $22,1 \%$ & \\
\hline Leite resfriado, esterilizado e pasteurizado & $0,0 \%$ & $20,4 \%$ & $9,6 \%$ & \\
\hline Produtos do laticinio e sorvetes & $0,0 \%$ & $0,0 \%$ & $20,8 \%$ & \\
\hline AUTONOMIA DE COMPRAS & $3,5 \%$ & $67,4 \%$ & $52,5 \%$ & $43,8 \%$ \\
\hline CIIVBP & $40,0 \%$ & $77,0 \%$ & $58 \%$ & $54,6 \%$ \\
\hline VAIVBP & $60,0 \%$ & $23,0 \%$ & $41,6 \%$ & $45,4 \%$ \\
\hline
\end{tabular}

\begin{tabular}{|c|c|c|c|c|}
\hline SETORES & $\begin{array}{c}\text { Leite de } \\
\text { vaca e de } \\
\text { outros } \\
\text { animais }\end{array}$ & \begin{tabular}{|c|} 
Leite resfriado, \\
esterilizado e \\
pasteurizado
\end{tabular} & $\begin{array}{c}\text { Produtos do } \\
\text { laticinio e } \\
\text { sorvetes }\end{array}$ & Lacteos \\
\hline Leite de vaca e de outros animais & $2,3 \%$ & $35,8 \%$ & $15,3 \%$ & $16,1 \%$ \\
\hline Leite re sfriado, esterilizado e pasteurizado & $0,0 \%$ & $15,6 \%$ & $6,7 \%$ & $10,5 \%$ \\
\hline Produtos do laticinio e sorvetes & $0,0 \%$ & $0,0 \%$ & $14,4 \%$ & $15,8 \%$ \\
\hline Insumos estaduais & $66,4 \%$ & $76,2 \%$ & $69,4 \%$ & $70,0 \%$ \\
\hline IMPORTAÇAO & $27,8 \%$ & $20,3 \%$ & $26,0 \%$ & $25,3 \%$ \\
\hline IMPOSTOS SOBRE PRODUÇÃO E PRODUTOS & $5,8 \%$ & $3,5 \%$ & $4,6 \%$ & $\frac{4,7 \%}{4,7 \%}$ \\
\hline Importação + Impostos & $33,6 \%$ & $23,8 \%$ & $30,6 \%$ & $30,0 \%$ \\
\hline Insumos estaduais + importados + impostos & $100,0 \%$ & $100,0 \%$ & $100,0 \%$ & $100,0 \%$ \\
\hline
\end{tabular}

Fonte: Dados da pesquisa (elaborado com base da MIP de 2008 de Minas Gerais). 
Anexo 2 - Correspondência entre produtos e setores da MIP de 2008 de MG.

\begin{tabular}{|c|c|c|c|c|c|}
\hline \multicolumn{3}{|r|}{80 Produtos } & \multicolumn{3}{|r|}{ 40 Setores } \\
\hline No & Código & Des crição & No & Código & Descrição \\
\hline 1 & 10102 & Milho em grão & 1 & 101 & Agricultura, silvicultura, exploração florestal \\
\hline 2 & 10104 & Cana-de-açúcar & & & \\
\hline 3 & 10105 & Soja em grão & & & \\
\hline 4 & 10106 & Outros produtos e serviços da lavoura & & & \\
\hline 5 & 10110 & Frutas citricas & & & \\
\hline 6 & 10111 & Café em grão & & & \\
\hline 7 & 10112 & Produtos da exploração florestal e da silvicultura & & & \\
\hline 8 & 10201 & Bovinos e outros animais vivos & 2 & 102 & Pecuária e pesca \\
\hline 9 & 10202 & Leite de vaca e de outros animais & & & \\
\hline 10 & 10203 & Suínos vivos & & & \\
\hline 11 & 10204 & Aves vivas & & & \\
\hline 12 & 10205 & Ovos de galinha e de outras aves & & & \\
\hline 13 & 20101 & Petróleo e gás natural & 3 & 201 & Indústria extrativa mineral \\
\hline 14 & 20201 & Minério de ferro & & & \\
\hline 15 & 20301 & Carvão mineral & & & \\
\hline 16 & 20302 & Minerais metálicos não-ferrosos & & & \\
\hline 17 & 20303 & Minerais não-metálicos & & & \\
\hline 18 & 30101 & Abate e preparação de produtos de carne & 4 & 301 & Alimentos e Bebidas \\
\hline 19 & 30103 & Carne de aves fresca, refrigerada ou congelada & & & \\
\hline 20 & 30105 & Conservas de frutas, legumes e outros vegetais & & & \\
\hline 21 & 30106 & Óleo de soja em bruto e tortas, bagaços e farelo de soja & & & \\
\hline 22 & 30107 & $\begin{array}{l}\text { Óleo de soja refinado, outros óleos vegetais exceto milho e } \\
\text { óleos de origem animal não comestiveis }\end{array}$ & & & \\
\hline 23 & 30109 & Leite res friado, es te rilizado e pas te urizado & & & \\
\hline 24 & 30110 & $\begin{array}{l}\text { Produtos do laticínio e sorvetes } \\
\text { Pode }\end{array}$ & & & \\
\hline 25 & 30111 & Arroz beneficiado e produtos derivados & & & \\
\hline 26 & 30112 & Farinha de trigo e derivados & & & \\
\hline 27 & 30114 & Óleos de milho, amidos e féculas vegetais e rações & & & \\
\hline 28 & 30115 & Produtos das usinas e do refino de açúcar & & & \\
\hline 29 & 30116 & Café torrado, moído e solúvel & & & \\
\hline 30 & 30118 & Outros produtos alimentares & & & \\
\hline 31 & 30119 & Bebidas & & & \\
\hline 32 & 30201 & $\begin{array}{ll}\text { Produtos do fumo } \\
\end{array}$ & 5 & 302 & Produtos do fumo \\
\hline 33 & 30301 & $\begin{array}{c}\text { Tecelagem, fiação e beneficiamento de algodão e de outros } \\
\text { têxteis }\end{array}$ & 6 & 303 & Têxteis \\
\hline 34 & 30303 & Fabricação outros produtos Têxteis & & & \\
\hline 35 & 30401 & Artigos do vestuário e acessórios & 7 & 304 & $\begin{array}{l}\text { Artigos do vestuário, acessórios, artefatos de couro e } \\
\text { calçados }\end{array}$ \\
\hline 36 & 30501 & $\begin{array}{c}\text { Preparação do couro e fabricação de artefatos - exclusive } \\
\text { calçados }\end{array}$ & & & \\
\hline 37 & 30502 & Fabricação de calçados & & & \\
\hline 38 & 30701 & Celulose e outras pastas para fabricação de papel & 8 & 307 & Celulose e produtos de papel \\
\hline 39 & 30702 & Papel e papelão, embalagens e artefatos & & & \\
\hline 40 & 30801 & Jornais, revistas, discos e outros produtos gravados & 9 & 308 & Jornais, revistas, discos \\
\hline 41 & 30906 & Outros produtos do refino de petróleo e coque & 10 & 309 & Refino de petróleo e coque \\
\hline 42 & 31001 & Álcool & 11 & 310 & Álcool \\
\hline 43 & 31101 & Produtos químicos inorgânicos & 12 & 311 & $\begin{array}{l}\text { Produtos químicos - inclusive resina, elastômeros, } \\
\text { tintas, vernizes e preparados diversos }\end{array}$ \\
\hline 44 & 31102 & Produtos químicos orgânicos & & & \\
\hline 45 & 31103 & Fabricação de resina e elastômeros & & & \\
\hline 46 & 31104 & Tintas, vernizes, esmaltes e lacas & & & \\
\hline 47 & 31105 & Produtos é preparados químicos diversos & & & \\
\hline 48 & 31301 & Produtos farmacêuticos & 13 & 313 & Produtos farmacêuticos \\
\hline 49 & 31401 & Defensivos agrícolas & 14 & 314 & Defensivos agrícolas \\
\hline 50 & 31501 & Perfumaria, sabões e artigos de limpeza & 15 & 315 & Perfumaria, higiene e limpeza \\
\hline 51 & 31801 & Artigos de borracha & 16 & 318 & Artigos de borracha e plástico \\
\hline 52 & 31802 & Artigos de plástico & & & \\
\hline 53 & 31901 & Cimento & 17 & 319 & Cimento \\
\hline 54 & 32001 & Outros produtos de minerais não-metálicos & 18 & 320 & Outros produtos de minerais não-metálicos \\
\hline 55 & 32101 & Gusa e ferro-ligas & 19 & 321 & Fabricação de aço e derivados \\
\hline 56 & 32102 & Semi-acabacados, laminados planos, longos e tubos de aço & & & \\
\hline 57 & 32201 & Produtos da metalurgia de metais não-ferrosos & 20 & 322 & Metalurgia de metais não-ferrosos \\
\hline 58 & 32202 & Fundidos de aço & & & \\
\hline 59 & 32301 & Produtos de metal - exclusive máquinas e equipamento & 21 & 323 & $\begin{array}{c}\text { Produtos de metal - exclusive máquinas e } \\
\text { equipamentos }\end{array}$ \\
\hline 60 & 32401 & Máquinas e equipamentos, inclusive manutenção e reparos & 22 & 324 & $\begin{array}{c}\begin{array}{c}\text { Máquinas e equipamentos, inclusive manutenção e } \\
\text { reparos }\end{array} \\
\text {. }\end{array}$ \\
\hline 61 & 32501 & Eletrodomésticos & 23 & 325 & $\begin{array}{l}\text { Eletrodomésticos e equipamentos eletro-eletrônicos, } \\
\text { científicos e hospitalares }\end{array}$ \\
\hline 62 & 32601 & Máquinas para escritório e equipamentos de informática & & & \\
\hline 63 & 32701 & Máquinas, aparelhos e materiais elétricos & & & \\
\hline 64 & 32801 & Material eletrônico e equipamentos de comunicações & & & \\
\hline 65 & 32901 & Aparelhos/instrumentos médico-hospitalar, medida e óptico & & & \\
\hline 66 & 33001 & Automóveis, camionetas e utilitários & 24 & 330 & $\begin{array}{c}\text { Automóveis, camionetas, utilitários, caminhões e } \\
\text { ônibus }\end{array}$ \\
\hline 67 & 33101 & Caminhões e ônibus & & & \\
\hline 68 & 33201 & Peças e acessórios para veículos automotores & 25 & 332 & $\begin{array}{l}\text { Outros equipamentos de transporte, peças e } \\
\text { acessórios para vé́culos automotores }\end{array}$ \\
\hline 69 & 33301 & Outros equipamentos de transporte & & & \\
\hline 70 & 33401 & Produtos de madeira e das indústrias diversas & 26 & 334 & Produtos de madeira, móveis e produtos das indústrias \\
\hline 71 & 33402 & Sucatas recicladas & & & \\
\hline 72 & 40101 & $\begin{array}{c}\text { Produção e distribuição de eletricidade, gás, água, esgoto e } \\
\text { limpeza urbana }\end{array}$ & 27 & 401 & Eletricidade e gás, água, esgoto e limpeza urbana \\
\hline 73 & 50101 & Construção civil & 28 & 501 & Construção \\
\hline 74 & 60101 & Comércio & 29 & 601 & Comércio \\
\hline 75 & 70101 & Transporte, armazenagem e correios & 30 & 701 & Transporte, armazenagem e correio \\
\hline 76 & 80101 & Serviços de informação & 31 & 801 & Serviços de informação \\
\hline 77 & 90101 & $\begin{array}{l}\text { Intermediação financeira, seguros e previdência } \\
\text { complementar e serviços relacionados }\end{array}$ & 32 & 901 & Intermediação financeira e seguros \\
\hline 78 & 100101 & Atividades imobiliárias e aluguéis & 33 & 1001 & Serviços imobiliários e aluguel \\
\hline 79 & 110101 & Serviços de manutenção e reparação & 34 & 1101 & Serviços de manutenção e reparação \\
\hline 80 & 110201 & Serviços de alojamento e alimentação & 35 & 1102 & Serviços de alojamento e a limentação \\
\hline 81 & 110301 & Serviços prestados às empresas & 36 & 1103 & Serviços prestados às empresas \\
\hline 82 & 110401 & Educação mercantil e Saúde mercantil & 37 & 1104 & Educação e saúde mercantis \\
\hline 83 & 110601 & Serviços prestados às famílias e associativos & 38 & 1106 & Serviços prestados às famílias e associativos \\
\hline 84 & 110701 & Serviços domésticos & 39 & 1107 & Serviços Domésticos \\
\hline 85 & 120101 & Administração pública & 40 & 1203 & Administração pública e seguridade social \\
\hline
\end{tabular}

